\title{
P2X7 Receptor Activation Induces Reactive Oxygen Species Formation and Cell Death in Murine EOC13 Microglia
}

\author{
Rachael Bartlett, $^{1,2}$ Justin J. Yerbury, ${ }^{1,2}$ and Ronald Sluyter ${ }^{1,2}$ \\ ${ }^{1}$ School of Biological Sciences, University of Wollongong, Wollongong, NSW 2522, Australia \\ ${ }^{2}$ Illawarra Health and Medical Research Institute, Wollongong, NSW 2522, Australia \\ Correspondence should be addressed to Ronald Sluyter; rsluyter@uow.edu.au
}

Received 14 September 2012; Revised 16 November 2012; Accepted 4 December 2012

Academic Editor: Sung-Jen Wei

Copyright (c) 2013 Rachael Bartlett et al. This is an open access article distributed under the Creative Commons Attribution License, which permits unrestricted use, distribution, and reproduction in any medium, provided the original work is properly cited.

\begin{abstract}
The P2X7 purinergic receptor is a ligand-gated cation channel expressed on leukocytes including microglia. This study aimed to determine if P2X7 activation induces the uptake of organic cations, reactive oxygen species (ROS) formation, and death in the murine microglial EOC13 cell line. Using the murine macrophage J774 cell line as a positive control, RT-PCR, immunoblotting, and immunolabelling established the presence of P2X7 in EOC13 cells. A cytofluorometric assay demonstrated that the P2X7 agonists adenosine- $5^{\prime}$-triphosphate (ATP) and $2^{\prime}\left(3^{\prime}\right)$-O-(4-benzoylbenzoyl) ATP induced ethidium ${ }^{+}$or YO-PRO- $1^{2+}$ uptake into both cell lines. ATP induced ethidium ${ }^{+}$uptake into EOC13 cells in a concentration-dependent manner, with an $\mathrm{EC}_{50}$ of $\sim 130 \mu \mathrm{M}$. The P2X7 antagonists Brilliant Blue G, A438079, AZ10606120, and AZ11645373 inhibited ATP-induced cation uptake into EOC13 cells by 75-100\%. A cytofluorometric assay demonstrated that P2X7 activation induced ROS formation in EOC13 cells, via a mechanism independent of $\mathrm{Ca}^{2+}$ influx and $\mathrm{K}^{+}$efflux. Cytofluorometric measurements of Annexin-V binding and 7AAD uptake demonstrated that P2X7 activation induced EOC13 cell death. The ROS scavenger N-acetyl-L-cysteine impaired both P2X7-induced EOC13 ROS formation and cell death, suggesting that ROS mediate P2X7-induced EOC13 death. In conclusion, P2X7 activation induces the uptake of organic cations, ROS formation, and death in EOC13 microglia.
\end{abstract}

\section{Introduction}

Microglia are the resident innate immune cells of the central nervous system (CNS) and play an important role in immune surveillance [1] and in the pathogenesis and progression of a number of CNS disorders [2]. Microglia are constantly mobile, spending time scanning the extracellular space of the CNS [1]. In response to brain injury or immunological stimuli, these cells become activated and undergo dramatic morphological and functional changes, which are highly dependent on the context of their activation [3]. Activated microglia phagocytose debris and peptides, present antigens, and produce a number of soluble factors. These factors may be inflammatory, regulatory, or cytotoxic in nature and include reactive oxygen species (ROS), nitric oxide (NO), proinflammatory and anti-inflammatory cytokines, prostaglandins, and growth factors $[4,5]$. Microglia can be both neuroprotective or neurotoxic when activated, depending on the factors they produce and the quantity and context in which they are released, with prolonged or excessive activation of these cells being associated with neuroinflammation and the progression of a number of CNS disorders [6]. The mechanisms behind enhanced microglial activation in these disorders and the features determining the balance between neuroprotection and neurotoxicity are not fully understood.

The P2X7 receptor is a trimeric ligand-gated cation channel belonging to the $\mathrm{P} 2 \mathrm{X}$ family of purinergic receptors [7]. P2X7 is predominately expressed on mononuclear leukocytes including macrophages and microglia and plays a role in inflammation and immunity [8]. In particular, P2X7 is currently receiving attention due to its possible roles in neuroinflammation [9]. Activation of P2X7 by extracellular adenosine- $5^{\prime}$-triphosphate (ATP), or the most potent P2X7 agonist, $2^{\prime}\left(3^{\prime}\right)$-O-(4-benzoylbenzoyl) ATP (BzATP), causes the passage of small cations including $\mathrm{Ca}^{2+}, \mathrm{Na}^{+}$, and $\mathrm{K}^{+}$ across the plasma membrane, as well as organic cations, such as the fluorescent dyes ethidium ${ }^{+}$and YO-PRO- ${ }^{2+}[7]$. 
Compared to other $\mathrm{P} 2 \mathrm{X}$ receptors, $\mathrm{P} 2 \mathrm{X} 7$ requires relatively high ATP concentrations for activation, with a half maximal effective concentration $\left(\mathrm{EC}_{50}\right)$ of $100-300 \mu \mathrm{M}$ [7]. Activation of P2X7 leads to a number of cell-specific downstream signalling events, including the formation of ROS and reactive nitrogen species [10], and either cell proliferation or death $[11,12]$.

Using molecular, immunochemical, and pharmacological techniques, we demonstrate in the current study that the murine microglial EOC13 cell line [13] expresses functional $\mathrm{P} 2 \mathrm{X} 7$. Activation of P2X7 by ATP in this cell line induces the uptake of organic cations, ROS formation, and cell death.

\section{Materials and Methods}

2.1. Reagents and Antibodies. RPMI-1640 and DMEM/F12 media, GlutaMAX, normal horse serum (NHS), $0.05 \%$ trypsin, YO-PRO- $1^{2+}, 2^{\prime}, 7^{\prime}$-dichlorodihydrofluorescein diacetate $\left(\mathrm{H}_{2} \mathrm{DCFDA}\right)$, and $2^{\prime}, 7^{\prime}$-difluorofluorescein diacetate (DAF-FM DA) were from Invitrogen (Grand Island, NY). Fetal bovine serum (FBS) (heat-inactivated before use) was from Bovogen Biologicals (East Keilor, Australia). ATP, BzATP, ethidium bromide, dimethyl sulfoxide (DMSO), glycerol gelatin, and the P2X7 antagonist Brilliant Blue $\mathrm{G}$ (BBG) were from Sigma-Aldrich (St. Louis, MO). The P2X7 antagonists A438079, AZ10606120, and AZ11645373 were from Tocris Bioscience (Ellisville, MO). Primers were from GeneWorks (Hindmarsh, Australia). Protease inhibitor cocktail tablets (complete, Mini, EDTA-free) and AnnexinV-Fluorescein were from Roche Diagnostics (Penzberg, Germany). SuperSignal West Pico Chemiluminescent Substrate was from Pierce (Rockford, IL). The viability dye 7-aminoactinomycin $\mathrm{D}$ (7AAD) and the ROS scavenger $\mathrm{N}$-acetyl-L-cysteine (NAC) were from Enzo Life Sciences (Plymouth Meeting, PA). The broad-spectrum ROS inhibitor diphenyleneiodonium (DPI) was from Cayman Chemical (Ann Arbor, MI). Phenyl-methyl-sulfonyl-fluoride (PMSF), $\mathrm{n}$-dodecyl $\beta$-D-maltoside, and ethylene glycol tetraacetic acid (EGTA) were from Amresco (Solon, $\mathrm{OH}$ ).

Cells preincubated with $\mathrm{H}_{2} \mathrm{O}$ soluble compounds (BBG, A438079, and AZ10606120) were compared to cells preincubated in the absence of each compound. Cells preincubated with DMSO soluble compounds (AZ11645373 and DPI) were compared to cells preincubated with DMSO alone. Solutions containing $40 \mathrm{mM}$ NAC were prepared in $\mathrm{NaCl}$ medium (140 mM NaCl, $5 \mathrm{mM} \mathrm{NaOH}, 5 \mathrm{mM} \mathrm{KCl}, 10 \mathrm{mM}$ HEPES, and $5 \mathrm{mM}$ glucose, $\mathrm{pH} 7.4$ ) and adjusted to $\mathrm{pH} 7.4$; cells were then preincubated in $\mathrm{NaCl}$ medium with or without NAC. When studied, antagonists/inhibitors were present during incubations with ATP.

Rabbit anti-mouse P2X7 (extracellular epitope) polyclonal antibody $(\mathrm{Ab})$ and rabbit anti-rat P2X7 (C-termini epitope) $\mathrm{Ab}$ (and corresponding blocking peptide) were from Alomone Labs (Jerusalem, Israel). Peroxidase-conjugated goat anti-rabbit IgG Ab was from Rockland Immunochemicals (Gilbertsville, PA). Cy3-conjugated donkey anti-rabbit IgG Ab was from Jackson ImmunoResearch (West Grove, $\mathrm{PA})$. Rat anti-mouse P2X7 monoclonal antibody (mAb) (clone HANO43) was from Enzo Life Sciences. Rat IgG2b isotype control mAb and allophycocyanin- (APC-) conjugated donkey anti-rat IgG Ab were from eBioscience (San Diego, CA).

2.2. Cell Lines. The murine macrophage J774 cell line, the murine microglial EOC13 cell line, and the murine lymphoblast LADMAC cell line, all originally obtained from the American Type Culture Collection (Manassas, VA), were kindly provided by Jasmyn Dunn (University of Queensland, Brisbane, Australia) (J774) and Iain Campbell (University of Sydney, Sydney, Australia) (EOC13 and LADMAC). J774 cells were maintained in RPMI-1640 medium containing $10 \%$ FBS and 2 mM GlutaMAX (complete RPMI medium). EOC13 cells were maintained in DMEM/F12 supplemented with 10\% FBS, 2 mM GlutaMAX, and 20\% LADMAC conditioned medium (complete DMEM medium). Cell lines were maintained at $37^{\circ} \mathrm{C}$ and $95 \%$ air $/ 5 \% \mathrm{CO}_{2}$ and passaged every 3-4 days. Quarterly mycoplasma testing was carried out using the MycoAlert Mycoplasma Detection Kit (Lonza, Rockland, $\mathrm{ME}$ ), as per the manufacturer's instructions. For experiments, cells were harvested by cell scraping unless otherwise stated.

2.3. Fluorescent Cation Dye Uptake Assay. Cells were washed in $\mathrm{NaCl}$ medium $(300 \times g$ for $5 \mathrm{~min})$, resuspended in $\mathrm{NaCl}$ medium, and equilibrated at $37^{\circ} \mathrm{C}$ for $5 \mathrm{~min}(1 \times$ $10^{5}$ cells $/ 1 \mathrm{~mL} /$ tube). Cells were then incubated with $25 \mu \mathrm{M}$ ethidium $^{+}$(or $1 \mu \mathrm{M}$ YO-PRO- ${ }^{2+}$ where indicated) in the absence or presence of the P2X7 agonists ATP or BzATP (as indicated) for $5 \mathrm{~min}$. In some experiments, ATP-induced cation uptake was assessed with cells suspended in $\mathrm{KCl}$ medium (150 mM KCl, $5 \mathrm{mM}$ glucose, and $10 \mathrm{mM}$ HEPES, $\mathrm{pH} 7.4$ ) or in $\mathrm{NaCl}$ medium containing $1 \mathrm{mM} \mathrm{CaCl}_{2}$ or $100 \mu \mathrm{M}$ EGTA. In other experiments, cells were preincubated in the absence or presence of P2X7 antagonists or the ROS scavenger NAC (as indicated) for 15 and $30 \mathrm{~min}$, respectively, prior to cation and ATP addition. Incubations with nucleotides were stopped by the addition of an equal volume of ice-cold $\mathrm{NaCl}$ medium containing $20 \mathrm{mM} \mathrm{MgCl} 2\left(\mathrm{MgCl}_{2}\right.$ medium) followed by centrifugation $(300 \times g$ for $5 \mathrm{~min})$. Cells were washed once with $\mathrm{NaCl}$ medium and events collected using a LSR II flow cytometer (BD Biosciences, San Diego, CA) (excitation $488 \mathrm{~nm}$, emission collected with 575/26 and $515 / 20$ band-pass filters for ethidium ${ }^{+}$and YO-PRO- $1^{2+}$, resp.). The mean fluorescence intensity (MFI) of relative cation uptake was determined using FlowJo software (Tree Star, Ashland, OR).

2.4. P2X7 Expression by RT-PCR. Total RNA isolation from cells was performed using the RNeasy Mini Kit (Qiagen, Hilden, Germany) as per the manufacturer's instructions. PCR amplification was performed as described previously [14] using SuperScript III One-Step RT-PCR System Platinum Taq DNA polymerase (Invitrogen) with 500 ng of RNA, and P2X7 forward ( $5^{\prime}$-ATATCCACTTCCCCGGCCAC- $3^{\prime}$ ) and reverse $\left(5^{\prime}\right.$-TCGGCAGTGATGGGACCAG- $\left.3^{\prime}\right)$ primers for 42 cycles $\left(94^{\circ} \mathrm{C}, 1 \mathrm{~min} ; 68^{\circ} \mathrm{C}, 1 \mathrm{~min} ; 72^{\circ} \mathrm{C}, 1 \mathrm{~min}\right)$. PCR products were separated on a $2 \%$ agarose gel in Tris-acetate 
EDTA buffer and visualised with ethidium bromide staining. Images of gels were collected using a Gel Logic 212 PRO imaging system (Carestream Health, Rochester, NY).

2.5. P2X7 Protein Detection by Immunoblotting. Cells were washed three times with phosphate-buffered saline (PBS) $(300 \times g$ for $5 \mathrm{~min})$ and lysed $\left(1 \times 10^{7}\right.$ cells $\left./ \mathrm{mL}\right)$ over $60 \mathrm{~min}$ in ice-cold lysis buffer $(50 \mathrm{mM}$ BisTris, $750 \mathrm{mM} \mathrm{6-}$ aminohexanoic acid, $1 \% \mathrm{n}$-dodecyl $\beta$-D-maltoside, $1 \mathrm{mM}$ PMSF, and protease inhibitor cocktail, $\mathrm{pH}$ 7.0). Cells were sheared by passing ten times through a $21 \mathrm{G}$ needle and stored at $-20^{\circ} \mathrm{C}$ until needed. Cells were then thawed and cleared $\left(16,000 \times g\right.$ at $4^{\circ} \mathrm{C}$ for $\left.10 \mathrm{~min}\right)$. Supernatants $(25 \mu \mathrm{g}$ protein/lane) were separated under reducing conditions (5\% $\beta$-mercaptoethanol) using a discontinuous SDS-PAGE system with a $4 \%$ stacking gel and $10 \%$ separating gel. Proteins were then transferred to nitrocellulose membranes (Bio-Rad, Hercules, CA) and blocked at $4^{\circ} \mathrm{C}$ overnight with Tris-buffered saline $(250 \mathrm{mM} \mathrm{NaCl}$ and $50 \mathrm{mM}$ Tris, $\mathrm{pH} 7.5)$ containing $0.2 \%$ Tween-20 and 5\% milk powder. The following day, nitrocellulose membranes were incubated at room temperature for $2 \mathrm{~h}$ with anti-mouse P2X7 Ab (1:500) in Tris-buffered saline containing $0.2 \%$ Tween-20 and $5 \%$ milk powder. Membranes were washed three times over $30 \mathrm{~min}$ with Tris-buffered saline containing $0.2 \%$ Tween-20 and then incubated at room temperature for $1 \mathrm{~h}$ with peroxidiseconjugated anti-IgG Ab $(1: 1000)$ in Tris-buffered saline containing $0.2 \%$ Tween-20 and 5\% milk powder. Membranes were washed as above and visualised using chemiluminescent substrate and Amersham Hyperfilm ECL (GE Healthcare, Little Chalfont, Buckinghamshire, UK). Images of films were collected using a GS-800 Calibrated Densitometer (Bio-Rad).

2.6. Cell Surface P2X7 Protein Detection by Flow Cytometry. Cells in $\mathrm{NaCl}$ medium containing $10 \% \mathrm{NHS}$ and $0.02 \%$ $\mathrm{NaN}_{3}\left(1 \times 10^{5}\right.$ cells $/ 200 \mu \mathrm{L} /$ tube $)$ were incubated with anti$\mathrm{P} 2 \mathrm{X} 7$ or rat IgG2b isotype control $\mathrm{mAb}(5 \mu \mathrm{g} / \mathrm{mL})$ at room temperature for $30 \mathrm{~min}$. Cells were then washed twice with $\mathrm{NaCl}$ medium $(300 \times g$ for $5 \mathrm{~min})$ and incubated with APCconjugated anti-rat IgG $\mathrm{Ab}(1.3 \mu \mathrm{g} / \mathrm{mL})$ and 7AAD (to exclude dead cells) for $30 \mathrm{~min}$ protected from light. Cells were washed once as above. Events were then collected using a LSR II flow cytometer (excitation $633 \mathrm{~nm}$, emission collected with 660/20 band-pass filter for APC; excitation $488 \mathrm{~nm}$, emission collected with $695 / 40$ band-pass filter for 7AAD). Relative cell-surface P2X7 was determined using FlowJo software and is expressed as the difference in the MFI of specific mAb labelling and isotype control labelling.

2.7. P2X7 Protein Detection by Confocal Microscopy. EOC13 or J774 cells in their respective complete culture medium were plated into 24 -well plates with $13 \mathrm{~mm}$ glass coverslips ( 5 $\times 10^{4}$ cells $/ 0.5 \mathrm{~mL} /$ well) and incubated at $37^{\circ} \mathrm{C}, 95 \%$ air $/ 5 \%$ $\mathrm{CO}_{2}$ overnight to allow time to adhere. The following day, cells were fixed with $4 \%$ paraformaldehyde in PBS at room temperature for $15 \mathrm{~min}$ and then washed three times with PBS over $10 \mathrm{~min}$. Cells were incubated with permeabilisation solution (PBS containing 0.1\% DMSO, 2\% NHS, and
$0.1 \%$ Triton $\mathrm{X}-100$ ) at room temperature for $10 \mathrm{~min}$ and washed three times with PBS. Cells were then blocked with $20 \%$ NHS in PBS at room temperature for $20 \mathrm{~min}$. Cells were incubated at $4^{\circ} \mathrm{C}$ overnight with anti-rat P2X7 Ab $(5 \mu \mathrm{g} / \mathrm{mL}$; preincubated for $1 \mathrm{~h}$ in the absence or presence of blocking peptide as per the manufacturer's instruction) in PBS containing 1\% BSA, 0.2\% NHS, and $0.05 \% \mathrm{NaN}_{3}$. Cells were then washed as above and incubated at room temperature for $1 \mathrm{~h}$ with Cy3-conjugated anti-rabbit IgG Ab $(15 \mu \mathrm{g} / \mathrm{mL})$ in PBS containing $0.2 \%$ NHS. Cells were washed as above and then the coverslips mounted onto slides with $50 \%(\mathrm{v} / \mathrm{v})$ glycerol gelatin in PBS. Coverslips were sealed with nail varnish. Cells were visualised using a DM IBRE inverted microscope and TCS SP confocal imaging system (Leica, Mannheim, Germany) (excitation $488 \mathrm{~nm}$, emission collected at 560-600 nm). Images were captured using Leica Confocal Software.

2.8. ROS Formation Assay. EOC13 cells in complete DMEM medium were plated into 24 -well plates $\left(5 \times 10^{4}\right.$ cells/ $0.5 \mathrm{~mL} /$ well) and incubated at $37^{\circ} \mathrm{C}, 95 \%$ air $/ 5 \% \quad \mathrm{CO}_{2}$ overnight. Cells were then incubated with $\mathrm{NaCl}$ medium containing $10 \mu \mathrm{M} \mathrm{H}_{2}$ DCFDA $(0.5 \mathrm{~mL} /$ well $)$ at $37^{\circ} \mathrm{C}, 95 \%$ air $/ 5 \%$ $\mathrm{CO}_{2}$, protected from light for $30 \mathrm{~min}$. The medium was removed, and cells were further incubated in $\mathrm{NaCl}$ medium (containing $1 \mathrm{mM} \mathrm{CaCl}_{2}$ ) in the absence or presence of $2 \mathrm{mM}$ $\mathrm{ATP}$ at $37^{\circ} \mathrm{C}, 95 \%$ air $/ 5 \% \mathrm{CO}_{2}$ for $15 \mathrm{~min}$. Incubations were stopped by the addition of an equal volume of ice-cold $\mathrm{MgCl}_{2}$ medium. Cells were harvested using $0.05 \%$ trypsin $(5 \mathrm{~min}$, $37^{\circ} \mathrm{C}$ ) and were washed once with $\mathrm{NaCl}$ medium. Events were collected using a LSR II flow cytometer (excitation $488 \mathrm{~nm}$, emission collected at 515/20 nm) and the MFI of relative dichlorofluorescein (DCF) determined using FlowJo software.

In some experiments, ATP-induced ROS formation was assessed in $\mathrm{KCl}$ medium, in $\mathrm{NaCl}$ medium in the absence of $1 \mathrm{mM} \mathrm{CaCl}$ or presence of $100 \mu \mathrm{M} \mathrm{EGTA}$, or in complete DMEM medium in the absence or presence of $10 \mu \mathrm{M}$ AZ10606120 (15 min preincubation, prior to ATP addition). As free $\mathrm{Ca}^{2+}$ lowers the concentration of $\mathrm{ATP}^{4-}$ [15], cells incubated in the absence of $1 \mathrm{mM} \mathrm{Ca}^{2+}$ were incubated with $1.4 \mathrm{mM}$ ATP to provide equimolar $\mathrm{ATP}^{4-}$ concentrations $(575 \mu \mathrm{M})$, as calculated using the Bound and Determined Program [16]. In other experiments, cells were preincubated in the absence or presence of AZ10606120, NAC, or DPI (as indicated) for 15,30 , and $30 \mathrm{~min}$, respectively, prior to ATP addition. Cells prior to harvesting were also visualised by differential interference contrast (DIC) imaging using an Eclipse TE2000 inverted microscope (Nikon, Tokyo, Japan) to examine cell morphology, and DIC images were captured using Image-Pro AMS (Version 6.1) (Media Cybernetics, Rockville, MD).

2.9. NO Formation Assay. EOC13 cells in complete DMEM medium were plated into 24 -well plates $\left(5 \times 10^{4}\right.$ cells $/ 0.5 \mathrm{~mL} /$ well) and incubated at $37^{\circ} \mathrm{C}, 95 \%$ air $/ 5 \% \mathrm{CO}_{2}$ overnight. Cells were then incubated with $\mathrm{NaCl}$ medium containing $10 \mu \mathrm{M}$ DAF-FM DA $(0.5 \mathrm{~mL} /$ well $)$ at $37^{\circ} \mathrm{C}, 95 \%$ air $/ 5 \% \mathrm{CO}_{2}$, 
protected from light for $30 \mathrm{~min}$. The medium was removed, and the cells were washed once. Cells were then preincubated with $\mathrm{NaCl}$ medium in the absence or presence of $10 \mu \mathrm{M}$ AZ10606120 at $37^{\circ} \mathrm{C}, 95 \%$ air $/ 5 \% \mathrm{CO}_{2}$ for $15 \mathrm{~min}$. Following this, cells were further incubated in the absence or presence of $1.4 \mathrm{mM}$ ATP for $15 \mathrm{~min}$. Incubations were stopped by the addition of an equal volume of ice-cold $\mathrm{MgCl}_{2}$ medium. Cells were harvested using $0.05 \%$ trypsin $\left(5 \mathrm{~min}, 37^{\circ} \mathrm{C}\right)$ and were washed once with $\mathrm{NaCl}$ medium. Events were collected using a LSR II flow cytometer (excitation $488 \mathrm{~nm}$, emission collected at 515/20 $\mathrm{nm}$ ) and the MFI of relative benzotriazole derivative determined using FlowJo software.

\subsection{Cell Death Assay. EOC13 cells in complete DMEM} medium were plated into 24 -well plates $\left(5 \times 10^{4}\right.$ cells $/ 0.5 \mathrm{~mL} /$ well) and incubated at $37^{\circ} \mathrm{C}, 95 \%$ air $/ 5 \% \mathrm{CO}_{2}$ overnight. Cells were then incubated with filter sterile ATP (as indicated) at $37^{\circ} \mathrm{C}, 5 \% \mathrm{CO}_{2}$ for $24 \mathrm{~h}$. In some experiments, cells were preincubated in the absence or presence of $10 \mu \mathrm{M}$ AZ10606120 or $40 \mathrm{mM}$ NAC for 15 or $30 \mathrm{~min}$, respectively, prior to ATP addition. In other experiments, cells were preincubated in the absence or presence of $40 \mathrm{mM} \mathrm{NAC}$ for $90 \mathrm{~min}$, with $2 \mathrm{mM}$ ATP added in the final $15-60 \mathrm{~min}$, and then the medium replaced and cells incubated at $37^{\circ} \mathrm{C}, 95 \%$ air $/ 5 \%$ $\mathrm{CO}_{2}$ for a further $24 \mathrm{~h}$. Following the $24 \mathrm{~h}$ incubations, cells were harvested from wells using $0.05 \%$ trypsin $\left(5 \mathrm{~min}, 37^{\circ} \mathrm{C}\right)$ and washed once with Annexin- $\mathrm{V}$ binding medium $(\mathrm{NaCl}$ medium containing $5 \mathrm{mM} \mathrm{CaCl}_{2}$ ). Cells were then incubated with Annexin-V binding medium containing Annexin-VFluorescein and 7AAD at room temperature protected from light for $15 \mathrm{~min}$. Events were collected using a LSR II flow cytometer (excitation $488 \mathrm{~nm}$, emission collected with 515/20 and 695/40 band-pass filters for Annexin-V-Fluorescein and 7AAD, resp.) and the MFI of Annexin-V-Fluorescein and 7AAD determined using FlowJo software. Quadrant markers were used to determine the percentage of Annexin$\mathrm{V}^{+} / 7 \mathrm{AAD}^{-}$, Annexin- $\mathrm{V}^{-} / 7 \mathrm{AAD}^{+}$, and Annexin- $\mathrm{V}^{+} / 7 \mathrm{AAD}^{+}$ cells. In some experiments, cells prior to harvesting were visualised by DIC imaging to examine cell morphology, and DIC images captured as outlined in Section 2.8.

2.11. Data Presentation and Statistical Analyses. Data is presented as the mean \pm SD. Differences between multiple treatments were compared by ANOVA paired with Tukey's HSD posttest using Prism 5 for Windows (Version 5.04) (GraphPad Software, San Diego, CA), with differences considered significant for $P<0.05$. Concentration response and inhibition curves were fitted using Prism 5 and assuming a variable slope, with normalised and nonnormalised response curves, respectively, selected to obtain the best fit. Estimates of $\mathrm{EC}_{50}$ values and half maximal inhibitory concentrations $\left(\mathrm{IC}_{50}\right)$ were obtained from individual fits of these plots.

\section{Results}

3.1. P2X7 Antagonists Inhibit ATP-Induced Ethidium ${ }^{+}$Uptake into J774 Macrophage Cells in a Concentration-Dependent Manner. The murine macrophage J774 cell line is well known to express functional P2X7 [17]. Moreover, our group has demonstrated the presence of functional P2X7 in various cell types using a fixed-time fluorescent cation uptake assay (e.g., $[14,18])$. Therefore, this technique was used to confirm the presence of P2X7 in J774 cells and to validate the use of this cell line as a positive control. Incubation of J774 cells with the P2X7 agonist ATP and the most potent P2X7 agonist BzATP induced significant ethidium ${ }^{+}$uptake into these cells compared to cells incubated in the absence of nucleotide (Figure 1(a)). In addition, incubation of J774 cells with ATP induced significant YO-PRO- $1^{2+}$ uptake compared to cells incubated in the absence of ATP (Figure 1(b)). However, ATP-induced YO-PRO- $1^{2+}$ uptake was significantly lower than ATP-induced ethidium ${ }^{+}$uptake (Figure 1(b)).

A number of highly specific P2X7 antagonists, including A438079 [19], AZ10606120 [20], and AZ11645373 [21], have recently become available. In addition, BBG is commonly used as a P2X7 antagonist in vitro and in vivo (e.g., [22, 23]). Therefore, to determine the optimum concentrations of these antagonists required to inhibit murine P2X7, J774 cells were preincubated in the absence or presence of varying concentrations of BBG, A438079, AZ10606120, and AZ11645373 and the ATP-induced ethidium ${ }^{+}$uptake assessed. Each antagonist impaired $1 \mathrm{mM}$ ATP-induced ethidium ${ }^{+}$uptake in a concentration-dependent manner, with $\mathrm{IC}_{50}$ values of $1.8 \pm$ $0.2,7.9 \pm 0.4,1.0 \pm 0.1$, and $1.5 \pm 0.1 \mu \mathrm{M}$, respectively (Figure 1(c)). AZ10606120 and A438079 completely inhibited ethidium ${ }^{+}$uptake at respective concentrations of 10 and $100 \mu \mathrm{M}$. In contrast, BBG and AZ11645373 were partial antagonists at the ATP concentration used ( $1 \mathrm{mM})$.

3.2. EOC13 Microglial Cells Express P2X7. To determine whether EOC13 microglial cells express P2X7, a series of experiments using J774 cells as a positive control were performed. Firstly, RNA was isolated from EOC13 and J774 cells and amplified by RT-PCR using primers for P2X7. Similar to J774 cells, EOC13 cells were found to express P2X7 mRNA, as evident from the 230 base pair band corresponding to the size of the predicted product (Figure $2(\mathrm{a})$ ). The presence of total P2X7 protein was determined by probing separated whole lysates of both cell lines with an anti-P2X7 Ab. Immunoblotting revealed one major protein band of $75 \mathrm{kDa}$ for both EOC13 and J774 cells (Figure 2(b)), corresponding to the predicted size of glycosylated P2X7. Moreover, both cell lines were incubated with an anti-P2X7 $\mathrm{mAb}$ and the presence of cell-surface P2X7 determined by flow cytometry. Immunolabelling demonstrated cell-surface P2X7 on both EOC13 and J774 cells, with MFIs of $13 \pm 2$ and $14 \pm 4$, respectively $(n=3)$ (Figure $2(\mathrm{c})$ ). Finally, both cell lines were stained with an anti-P2X7 Ab and analysed by confocal microscopy. This similarly demonstrated the presence of cell-surface P2X7, as well as intracellular P2X7, with bright staining observed on all cells (Figure 2(d)). Preincubation of the anti-P2X7 Ab with blocking peptide completely abrogated the detection of P2X7 in both cell lines (data not shown). Together, these results indicate that P2X7 is expressed in EOC13 cells.

3.3. EOC13 Microglial Cells Express Functional P2X7. To determine whether P2X7 was functional in EOC13 cells, 

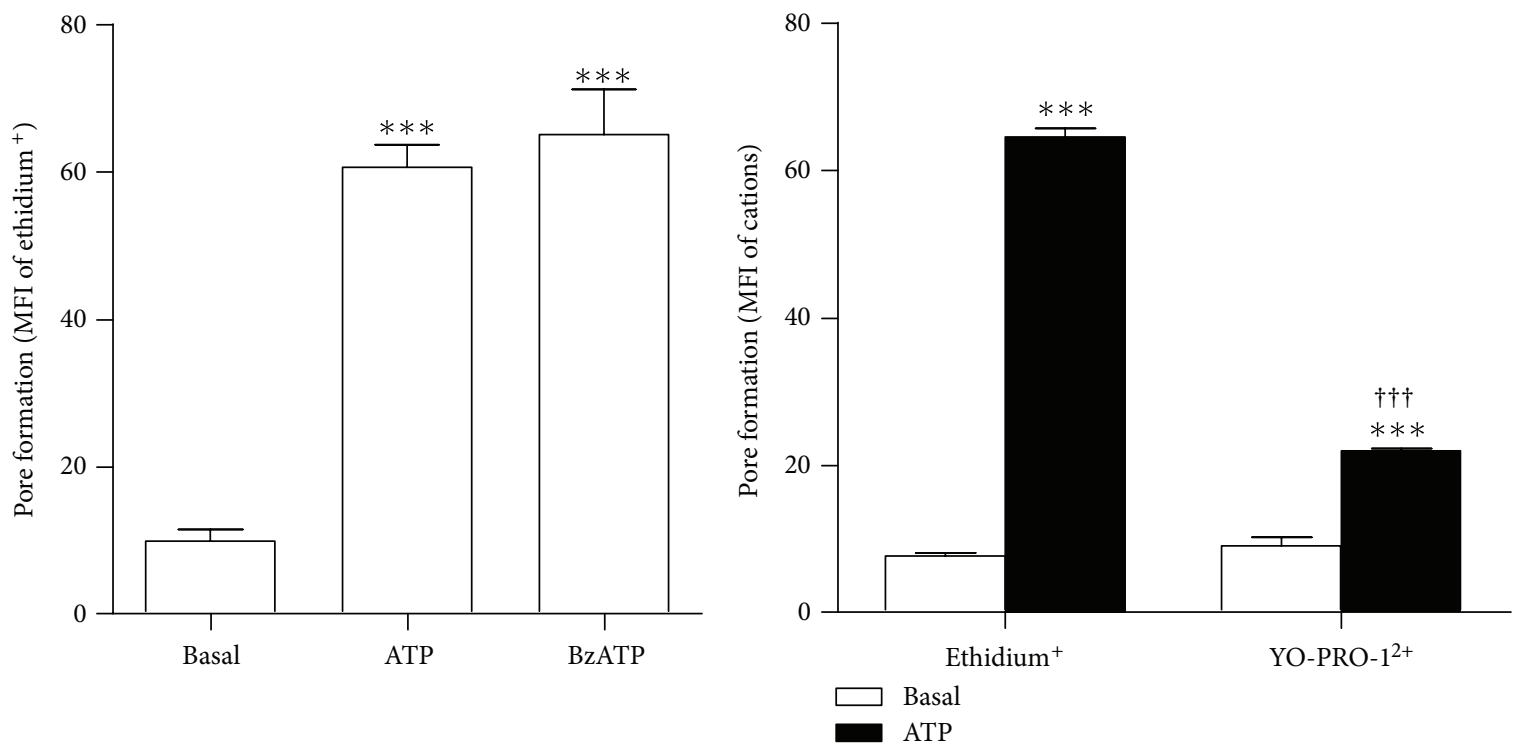

(a)

(b)

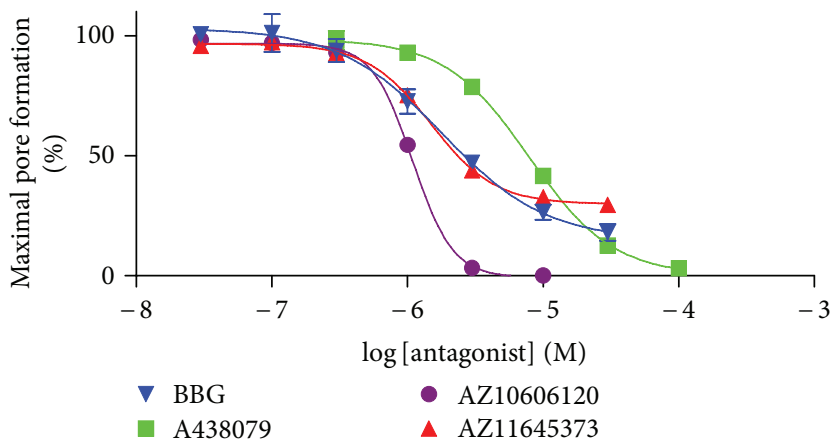

(c)

FIGURE 1: P2X7 antagonists inhibit ATP-induced ethidium ${ }^{+}$uptake into J774 macrophage cells in a concentration-dependent manner. (a and b) J774 cells in $\mathrm{NaCl}$ medium were incubated with (a and b) $25 \mu \mathrm{M}$ ethidium ${ }^{+}$or (b) $1 \mu \mathrm{M}$ YO-PRO- $1^{2+}$ in the absence (basal) or presence of ( $\mathrm{a}$ and b) $1 \mathrm{mM}$ ATP or (a) $0.1 \mathrm{mM} \mathrm{BzATP}$ at $37^{\circ} \mathrm{C}$ for $5 \mathrm{~min}$. (c) Cells in NaCl medium were preincubated with Brilliant Blue G (BBG), $\mathrm{A} 438079, \mathrm{AZ10606120}$, and AZ11645373 (as indicated) at $37^{\circ} \mathrm{C}$ for $15 \mathrm{~min}$. Ethidium ${ }^{+}(25 \mu \mathrm{M})$ was then added, and cells were incubated in the absence or presence of $1 \mathrm{mM}$ ATP at $37^{\circ} \mathrm{C}$ for $5 \mathrm{~min}$. (a-c) Incubations were stopped by the addition of $\mathrm{MgCl}_{2}$ medium and centrifugation. Mean fluorescence intensity (MFI) of fluorescent cation uptake (pore formation) was determined by flow cytometry. (a and b) Results shown as means $\pm \mathrm{SD}, n=3 ;{ }^{* * *} P<0.001$ compared to corresponding basal; ${ }^{\dagger \dagger \dagger} P<0.001$ compared to corresponding ATP. (c) Curves presented as a percentage of the maximal ATP-induced ethidium ${ }^{+}$uptake and expressed as the mean \pm SD, $n=3-4$.

the fixed-time ethidium ${ }^{+}$uptake assay was performed. Both ATP and BzATP were found to induce significant ethidium ${ }^{+}$ uptake into EOC13 cells compared to cells incubated in the absence of nucleotide (Figure 3(a)). Next, EOC13 cells were incubated with increasing concentrations of ATP. ATP induced ethidium ${ }^{+}$uptake in a concentration-dependent manner, with maximal uptake obtained at an ATP concentration of $1 \mathrm{mM}$ and with an $\mathrm{EC}_{50}$ of $130 \pm 30 \mu \mathrm{M}$ (Figure $3(\mathrm{~b})$ ). Subsequent characterisations of P2X7 in EOC13 microglia were performed using this maximal concentration of ATP (1 mM).

To determine if the observed ATP-induced ethidium ${ }^{+}$ uptake into EOC13 cells was mediated by P2X7, cells were preincubated in the absence or presence of P2X7 antagonists at inhibitory concentrations optimal for $1 \mathrm{mM}$ ATPinduced ethidium ${ }^{+}$uptake in J774 cells, as demonstrated above (Figure 1(c)). Preincubation of EOC13 cells with $30 \mu \mathrm{M}$ BBG, $100 \mu \mathrm{M}$ A438079, $10 \mu \mathrm{M}$ AZ10606120, and $30 \mu \mathrm{M}$ AZ11645373 resulted in significant impairment of ATP-induced ethidium ${ }^{+}$uptake by $75 \pm 2,90 \pm 1,100 \pm 0$, and $99 \pm 1 \%$, respectively (Figure 3(c)). None of the P2X7 antagonists except AZ1 1645373 significantly altered the basal ethidium $^{+}$uptake into EOC13 cells. Again with the exception of AZ11645373, which reduced the amount of gated viable cells by $\sim 30 \%$, cell viability (as assessed by forward and side scatter) was similar between treatments (data not shown). 


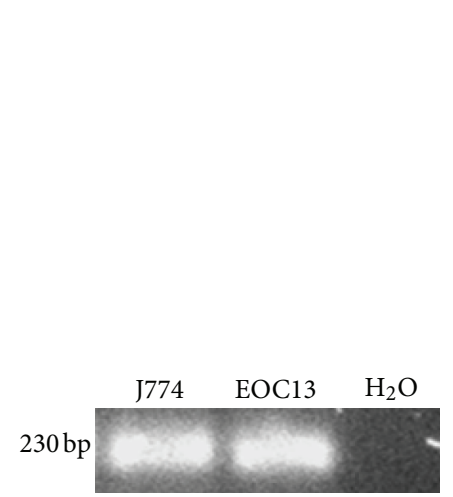

(a)

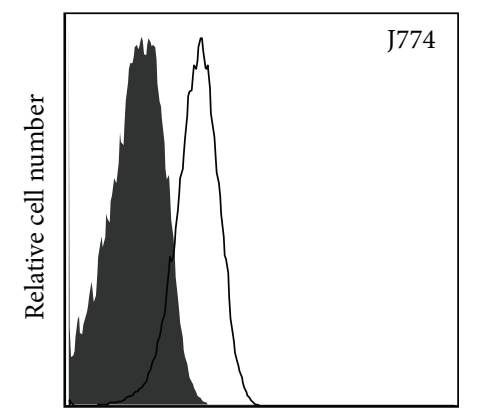

Relative P2X7 expression

(c)
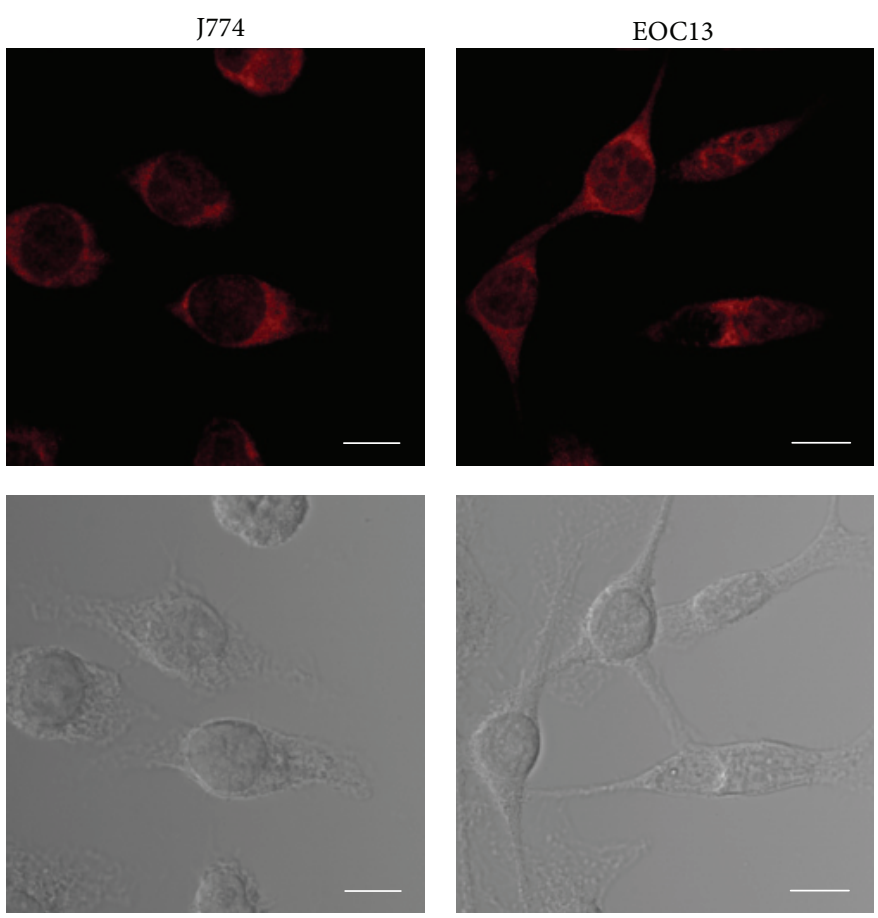

(d)

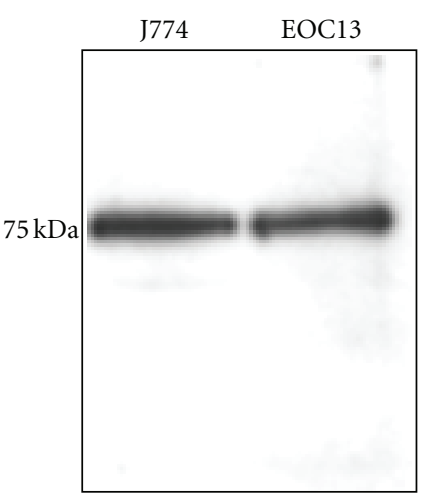

(b)

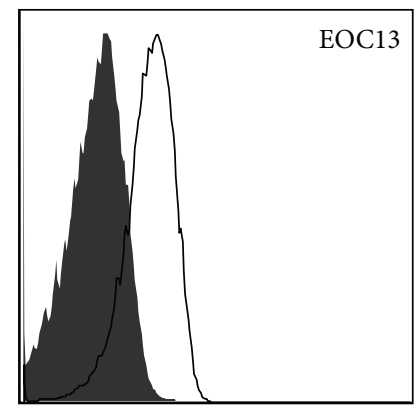

EOC13

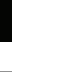




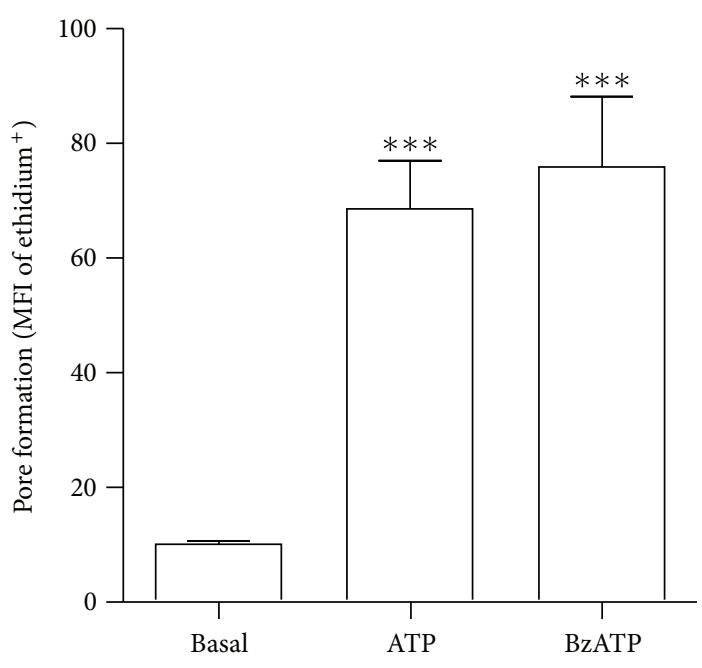

(a)
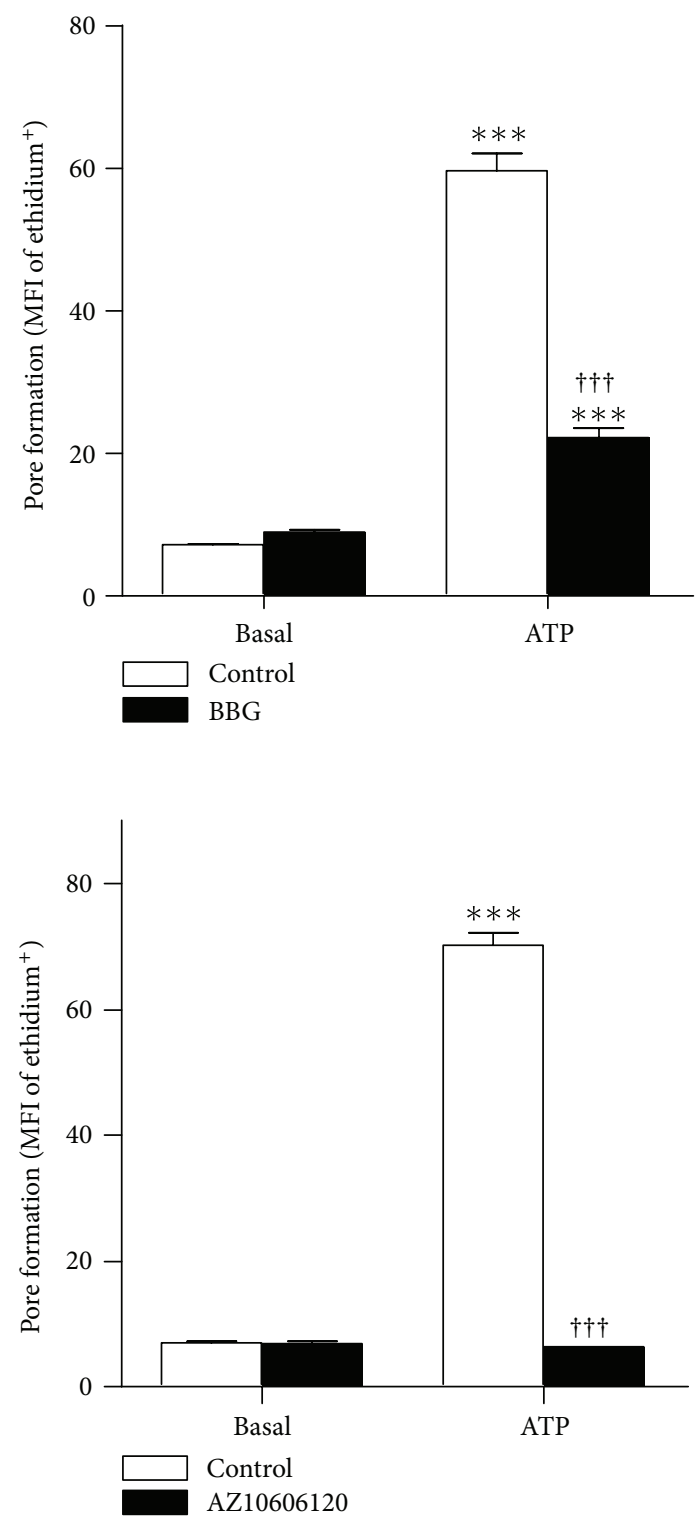

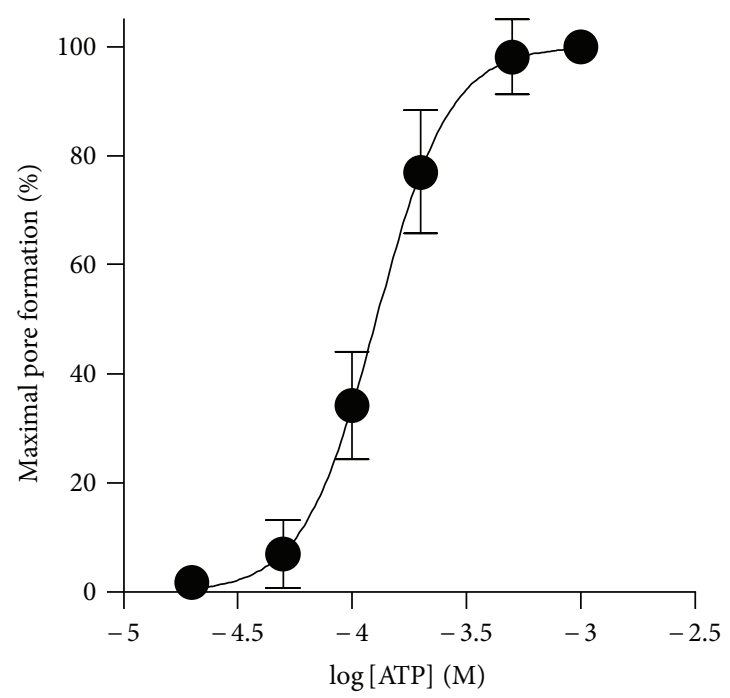

(b)
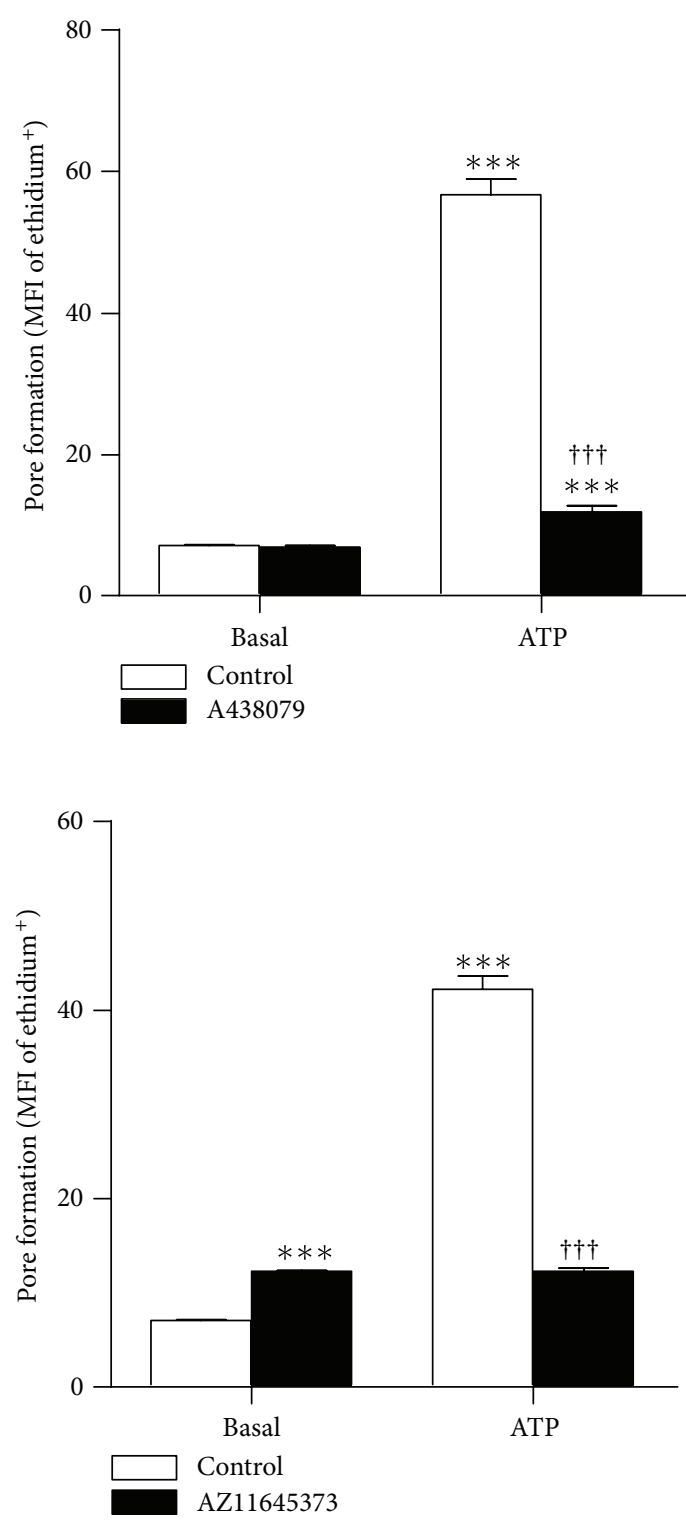

(c)

FIgURE 3: Continued. 


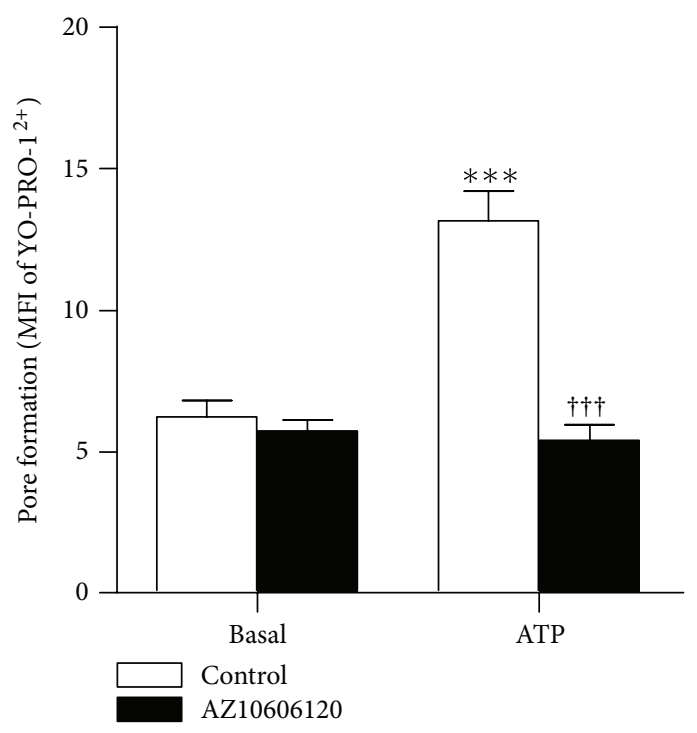

(d)

FIGURE 3: EOC13 microglial cells express functional P2X7. (a and b) EOC13 cells in $\mathrm{NaCl}$ medium were incubated with $25 \mu \mathrm{M}$ ethidium ${ }^{+}$ in the absence (basal) or presence of (a) $1 \mathrm{mM} \mathrm{ATP}, 0.1 \mathrm{mM} \mathrm{BzATP}$, or (b) varying concentrations of ATP (as indicated) at $37^{\circ} \mathrm{C}$ for $5 \mathrm{~min}$. (c and d) Cells in $\mathrm{NaCl}$ medium were preincubated in the absence (control) or presence of (c) $30 \mu \mathrm{M}$ Brilliant Blue G (BBG), $100 \mu \mathrm{M}$ A438079, $30 \mu \mathrm{M}$ AZ11645373, or (c and d) $10 \mu \mathrm{M} \mathrm{AZ10606120}$ at $37^{\circ} \mathrm{C}$ for $15 \mathrm{~min}$. (c) Ethidium ${ }^{+}(25 \mu \mathrm{M})$ or $(\mathrm{d}) \mathrm{YO}-\mathrm{PRO}-1^{2+}(1 \mu \mathrm{M})$ was then added, and ( $\mathrm{c}$ and $\mathrm{d}$ ) cells were incubated in the absence (basal) or presence of $1 \mathrm{mM} \mathrm{ATP}$ at $37^{\circ} \mathrm{C}$ for $5 \mathrm{~min}$. (a-d) Incubations were stopped by the addition of $\mathrm{MgCl}_{2}$ medium and centrifugation. Mean fluorescence intensity (MFI) of fluorescent cation uptake (pore formation) was determined by flow cytometry. (a, c, and d) Results shown as means $\pm \mathrm{SD}, n=3$; $^{* * *} P<0.001$ compared to corresponding basal; ${ }^{\dagger \dagger \dagger} P<0.001$ compared to corresponding ATP in the absence of antagonist. (b) Curve presented as a percentage of the maximal ATP-induced ethidium ${ }^{+}$ uptake and expressed as the mean $\pm \mathrm{SD}, n=3$.

To determine if $\mathrm{P} 2 \mathrm{X} 7$ activation could induce the uptake of a second organic cation into EOC13 cells, cells were preincubated in the absence or presence of AZ10606120, and ATPinduced YO-PRO- ${ }^{2+}$ uptake examined. Similar to ethidium ${ }^{+}$ uptake, $1 \mathrm{mM}$ ATP induced significant YO-PRO- $1^{2+}$ uptake into EOC13 cells compared to cells incubated in the absence of ATP (Figure 3(d)). Moreover, preincubation of cells with $10 \mu \mathrm{M}$ AZ10606120 resulted in complete inhibition of ATPinduced YO-PRO- $1^{2+}$ uptake (Figure $3(\mathrm{~d})$ ). Incubation with AZ10606120 did not significantly alter the basal YO-PRO- ${ }^{2+}$ uptake (Figure 3(d)). Furthermore, cell viability (as assessed by forward and side scatter) was similar between treatments (data not shown). Collectively, these results indicate that $\mathrm{P} 2 \mathrm{X} 7$ is functional in EOC13 cells.

\subsection{P2X7 Activation Induces ROS Formation in EOC13} Microglial Cells. P2X7 activation has been reported to induce ROS formation in a number of cell types, including primary microglia $[24,25]$. Thus, ATP-induced ROS formation in the EOC13 cell line was investigated using the ROS sensitive probe DCF. Cells loaded with $\mathrm{H}_{2}$ DCFDA (which is converted to DCF inside cells) were incubated in the absence or presence of ATP, and the subsequent ROS formation analysed by flow cytometry. As extracellular $\mathrm{Ca}^{2+}$ has been reported to be important for P2X7-induced ROS formation in a number of cell types $[24,26,27]$, assays were initially conducted in the presence of $1 \mathrm{mM} \mathrm{Ca}^{2+}$. However, due to the inhibitory action of $\mathrm{Ca}^{2+}$ on P2X7 [15], assays were initially conducted with $2 \mathrm{mM}$ ATP. Incubation with $2 \mathrm{mM}$ ATP induced significant ROS formation in EOC13 cells compared to cells incubated in the absence of ATP (MFI of ROS formation $16.3 \pm 0.6$ and $5.18 \pm 0.06$, resp., $P<0.001, n=3$ ). Furthermore, preincubation of cells with $10 \mu \mathrm{M}$ AZ10606120 resulted in complete inhibition of ATP-induced ROS formation (Figure $4(\mathrm{a})$ ), indicating that this process is mediated by $\mathrm{P} 2 \mathrm{X} 7$ activation. As for cation uptake (Figure 3), AZ10606120 did not significantly alter the basal ROS formation (Figure 4(a)) or cell viability (as assessed by forward and side scatter) (data not shown).

P2X7 is a ligand-gated cation channel [7]; therefore the possible roles for cation fluxes in P2X7-induced ROS formation were next investigated. P2X7-induced ROS formation has been reported to be partially dependent on $\mathrm{Ca}^{2+}$ influx in human promyelocytes [26] and rat submandibular gland cells [27]. Thus, to determine if $\mathrm{Ca}^{2+}$ influx is required for P2X7-mediated ROS formation in EOC13 cells, ATPinduced ROS formation in the absence and presence of $\mathrm{Ca}^{2+}$ was investigated. For this comparison, equivalent amounts of $\mathrm{ATP}^{4-}(575 \mu \mathrm{M})$ were used by adding 1.4 or $2 \mathrm{mM}$ ATP to $\mathrm{NaCl}$ medium nominally free of $\mathrm{Ca}^{2+}$ or containing $1 \mathrm{mM}$ $\mathrm{Ca}^{2+}$, respectively. ATP induced significant ROS formation in both the absence and presence of $1 \mathrm{mM} \mathrm{Ca}^{2+}$ compared 


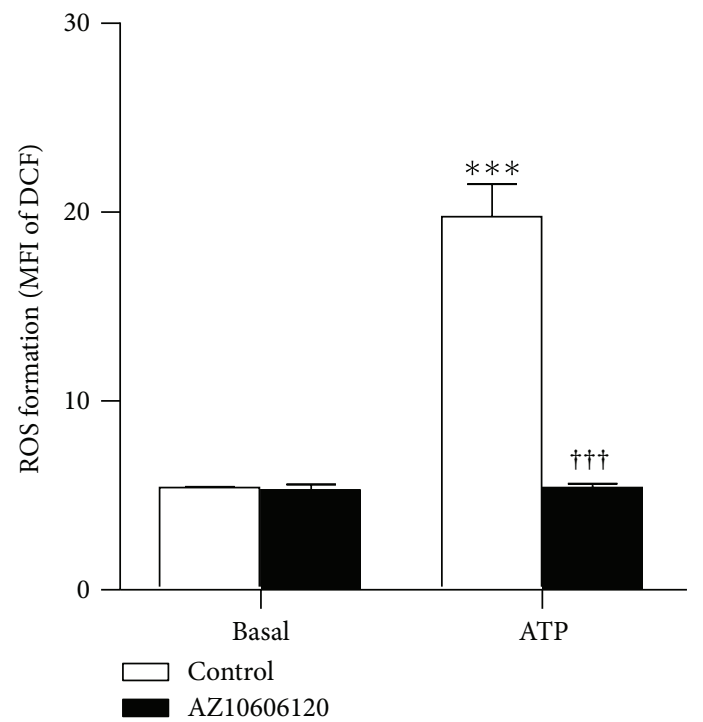

(a)
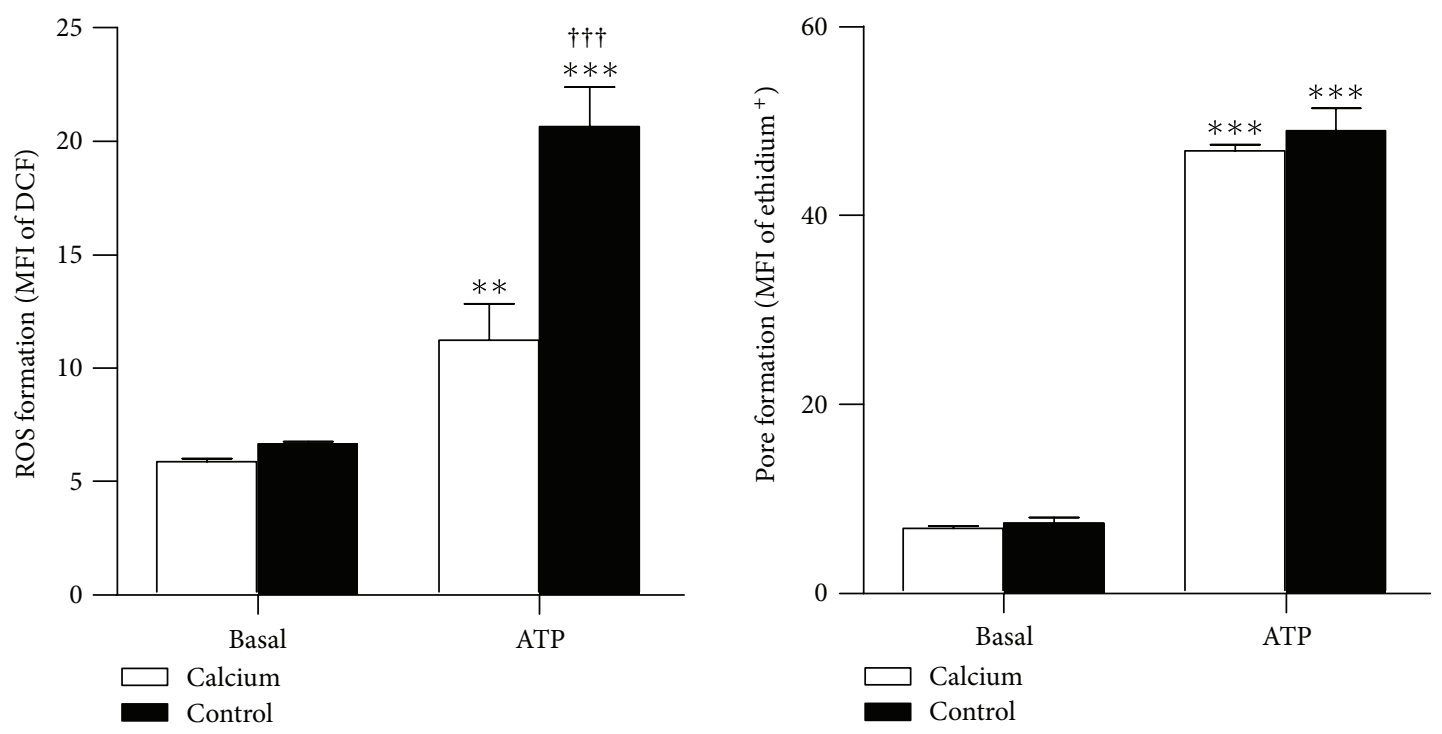

(b)
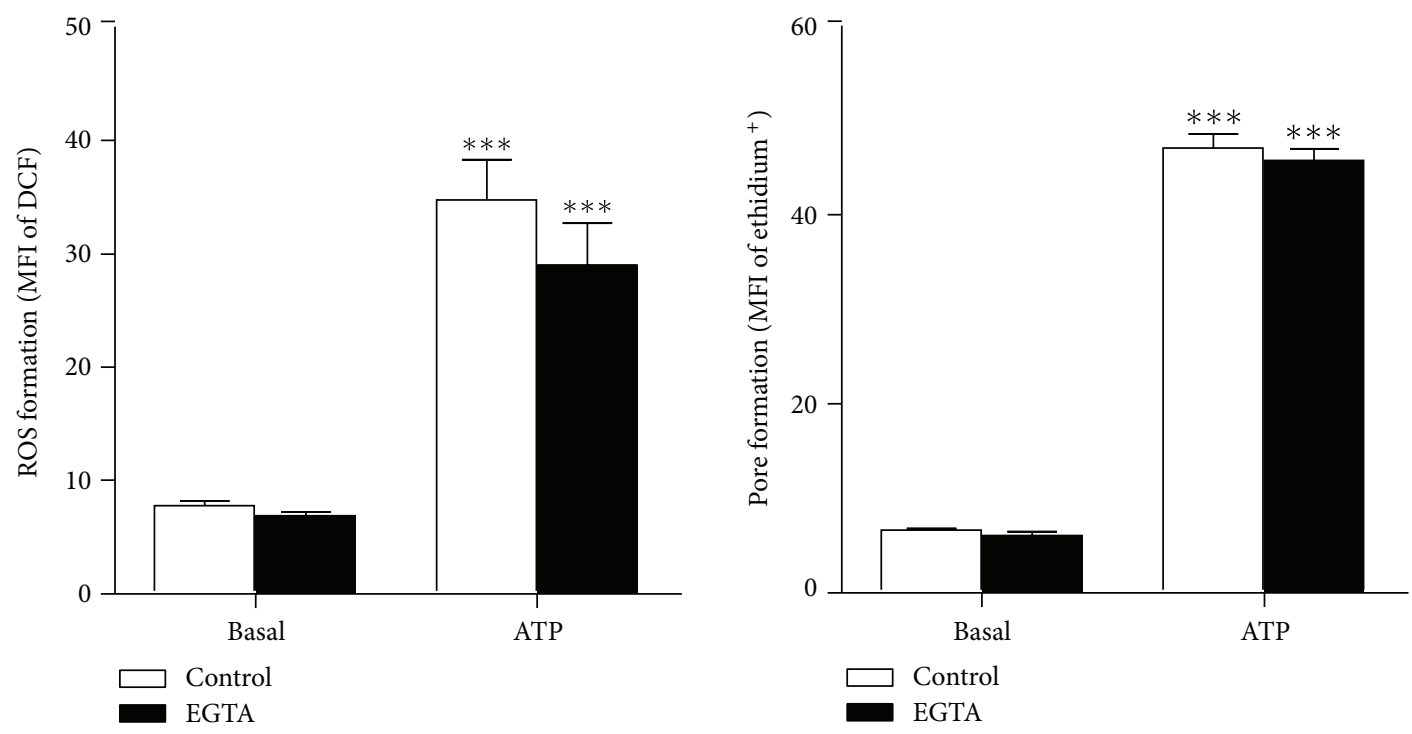

(c)

FIgURE 4: Continued. 

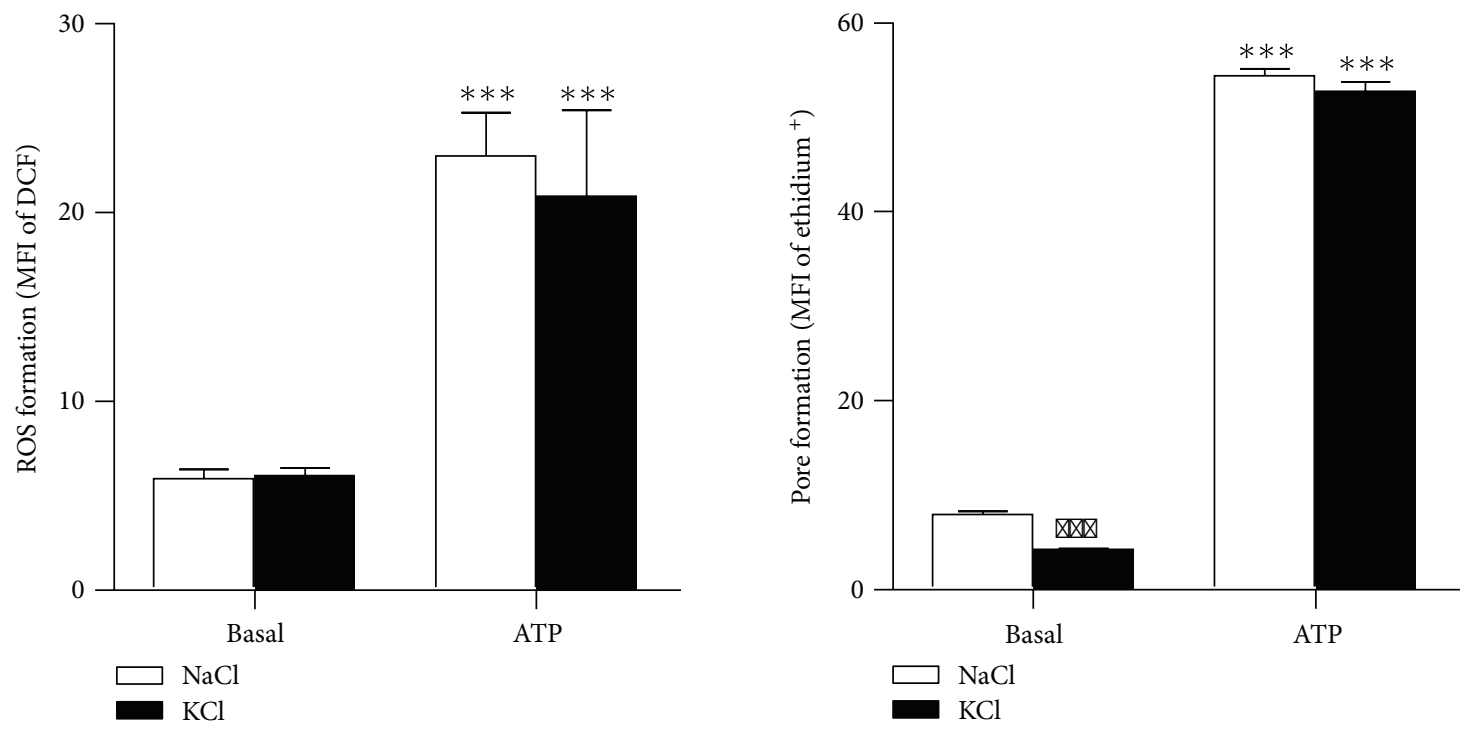

(d)

FIGURE 4: P2X7 activation induces ROS formation in EOC13 microglial cells. (Left panels) Adherent DCF-loaded EOC13 cells or (right panels) suspended EOC13 cells in (a) $\mathrm{NaCl}$ medium containing $1 \mathrm{mM} \mathrm{Ca}^{2+}$ (preincubated in the absence (control) or presence of $10 \mu \mathrm{M}$ $\mathrm{AZ10606120}$ at $37^{\circ} \mathrm{C}$ for $15 \mathrm{~min}$ ), (b) $\mathrm{NaCl}$ medium in the absence (control) or presence of $1 \mathrm{mM} \mathrm{Ca}^{2+}$, (c) $\mathrm{NaCl}$ medium in the absence (control) or presence of $100 \mu \mathrm{M}$ EGTA, or (d) $\mathrm{NaCl}$ or $\mathrm{KCl}$ medium were (a-d) incubated in the absence (basal) or presence of $575 \mu \mathrm{M}$ ATP ${ }^{4-}$ $\left(2 \mathrm{mM}\right.$ or $1.4 \mathrm{mM}$ ATP as explained in Section 2.8 ) at $37^{\circ} \mathrm{C}$ for (left panels) $15 \mathrm{~min}$ or (right panels) $5 \mathrm{~min}$ in the presence of $25 \mu \mathrm{M}$ ethidium ${ }^{+}$. (a-d) Incubations were stopped by the addition of $\mathrm{MgCl}_{2}$ medium and centrifugation. Mean fluorescence intensities (MFI) of (left panels) DCF (ROS formation) or (right panels) ethidium ${ }^{+}$uptake (pore formation) were determined by flow cytometry and results shown as means $\pm \mathrm{SD}, n=3 ;{ }^{* * *} P<0.001$ or ${ }^{* *} P<0.01$ compared to corresponding basal; ${ }^{\dagger \dagger} P<0.001$ compared to corresponding ATP.

to similarly treated cells in the absence of ATP (Figure $4(\mathrm{~b}))$. Cells incubated in the absence of $\mathrm{Ca}^{2+}$ had significantly higher ATP-induced ROS formation compared to those incubated in the presence of $\mathrm{Ca}^{2+}$. In contrast, ATPinduced ethidium ${ }^{+}$uptake (P2X7 function) was similar in cells incubated in the absence or presence of $\mathrm{Ca}^{2+}$ (Figure 4(b)), indicating that the differences in ATP-induced ROS formation were not due to altered P2X7 function.

$\mathrm{NaCl}$ medium may contain nominal amounts of $\mathrm{Ca}^{2+}$. Thus, to further exclude a role for $\mathrm{Ca}^{2+}$ in P2X7-mediated ROS formation in EOC13 cells, ATP-induced ROS formation was investigated in the absence and presence of the $\mathrm{Ca}^{2+}$ chelator EGTA. Incubation with $1.4 \mathrm{mM}$ ATP induced significant but similar amounts of ROS formation in both the absence and presence of $100 \mu \mathrm{M}$ EGTA compared to similarly treated cells in the absence of ATP (Figure 4(c)). Again, ATPinduced ethidium ${ }^{+}$uptake was similar in cells incubated in the absence or presence of EGTA (Figure 4(c)).

Finally, the role of $\mathrm{K}^{+}$in P2X7-induced ROS formation in EOC13 cells was investigated. Both ROS and $\mathrm{K}^{+}$efflux have been reported to be involved in interleukin- $1 \beta$ (IL-1 $\beta$ ) release from monocytes, although whether these downstream processes are linked is yet to be established [28]. Thus, to determine if $\mathrm{K}^{+}$efflux is involved in P2X7-mediated ROS formation in EOC13 cells, ATP-induced ROS formation was compared with cells in $\mathrm{NaCl}$ medium and $\mathrm{KCl}$ medium, which prevents the loss of intracellular $\mathrm{K}^{+}$. Incubation with
$1.4 \mathrm{mM}$ ATP induced significant ROS formation in both $\mathrm{NaCl}$ and $\mathrm{KCl}$ media, with similar levels of ROS formation in both media (Figure 4(d)). Likewise, ATP-induced ethidium ${ }^{+}$ uptake was similar in $\mathrm{NaCl}$ and $\mathrm{KCl}$ media (Figure $4(\mathrm{~d})$ ), indicating that the inability of high extracellular $\mathrm{K}^{+}$to impair ATP-induced ROS formation was not due to altered P2X7 function.

To confirm that P2X7 activation induced ROS formation in EOC13 microglia, DCF-loaded cells in $\mathrm{NaCl}$ medium were preincubated in the absence or presence of the ROS scavenger NAC, before incubation in the absence or presence of ATP. As above (Figure 4), 1.4 mM ATP induced significant ROS formation (Figure 5(a)). Preincubation with $40 \mathrm{mM} \mathrm{NAC}$ inhibited ATP-induced ROS formation by $73.7 \pm 0.3 \%$ (Figure 5(a)). Basal ROS formation (Figure 5(a)) and cell viability (as assessed by forward and side scatter) (data not shown) were similar between treatments. Preincubation of cells with 40 mM NAC inhibited ATP-induced ethidium ${ }^{+}$uptake by $30 \pm 2 \%$ (Figure 5(b)). Thus, the inhibitory effect of NAC on P2X7-induced ROS formation may be partially attributed to inhibition of P2X7 itself. However, incubation with NAC and ATP, but not either compound alone, reduced the amount of gated viable cells by $\sim 40 \%$ in the ethidium ${ }^{+}$uptake assay (as assessed by forward and side scatter) (data not shown). This suggests that the inhibitory action of NAC on ATP-induced ethidium $^{+}$uptake may be a result of cytotoxicity in this assay.

To confirm that NAC did not induce morphological changes or cause cytotoxicity under the conditions used for 


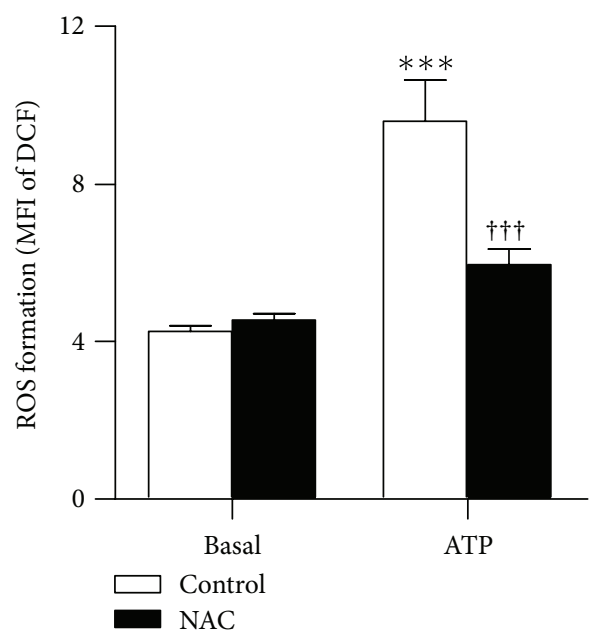

(a)
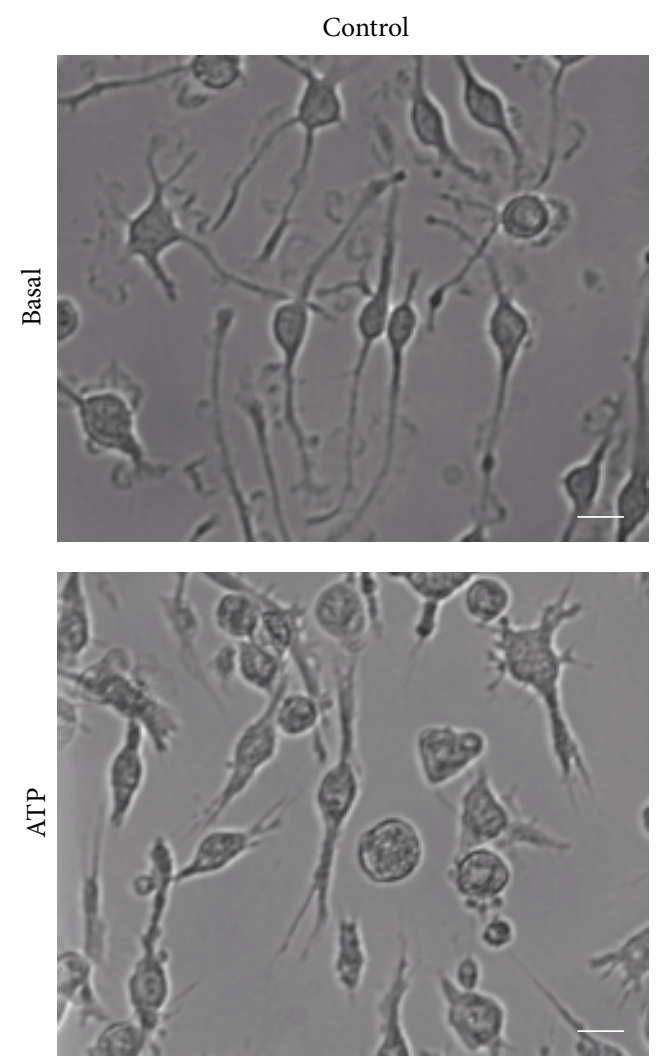

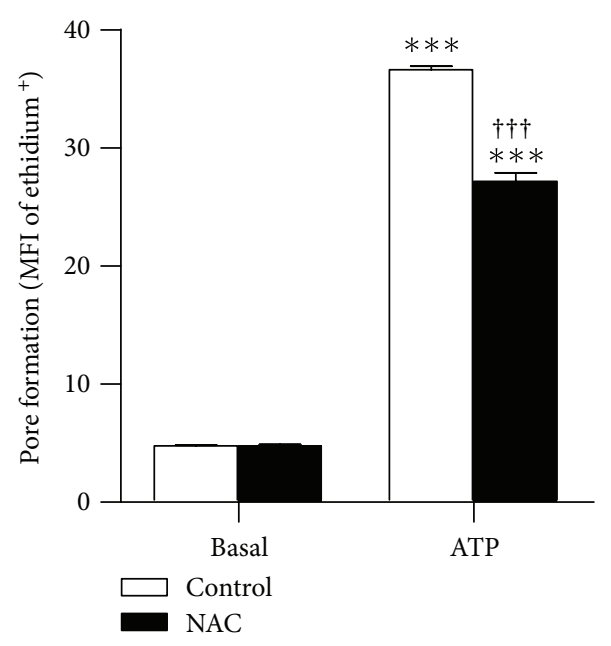

(b)
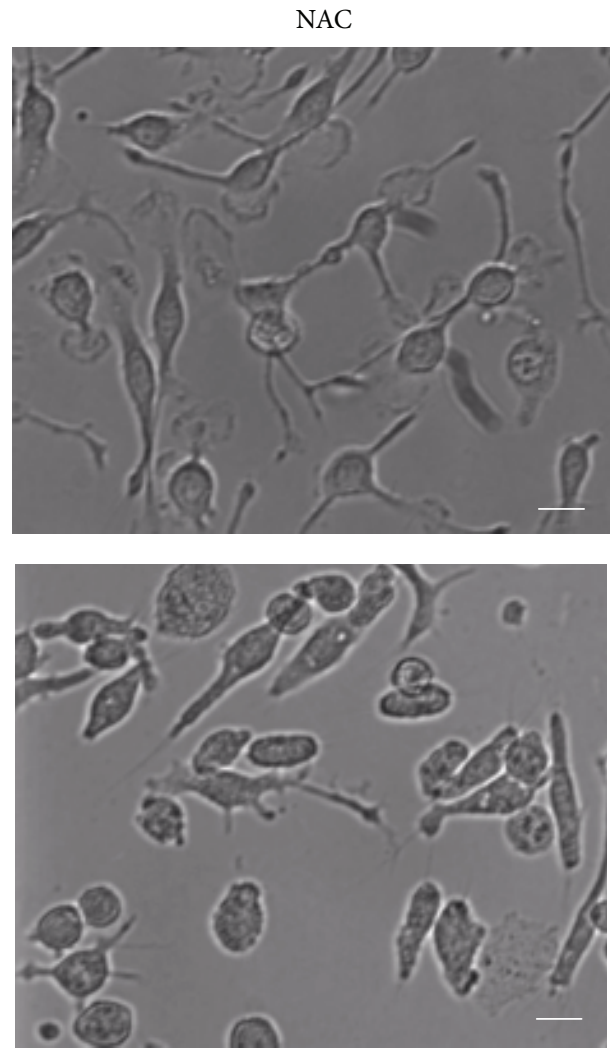

(c)

FIgURE 5: The ROS scavenger NAC inhibits P2X7-induced ROS and pore formation in EOC13 microglial cells. (a and c) Adherent DCFloaded EOC13 cells or (b) suspended EOC13 cells in NaCl medium were preincubated in the absence (control) or presence of 40 mM NAC at $37^{\circ} \mathrm{C}$ for $30 \mathrm{~min}$ and then in the absence (basal) or presence of $1.4 \mathrm{mM}$ ATP for (a and c) $15 \mathrm{~min}$ or (b) 5 min in the presence of $25 \mu \mathrm{M}$ ethidium ${ }^{+}$. ( $\mathrm{a}-\mathrm{c}$ ) Incubations were stopped by the addition of $\mathrm{MgCl}_{2}$ medium and ( $\mathrm{a}$ and $\mathrm{b}$ ) centrifugation. (a and $\mathrm{b}$ ) Mean fluorescence intensities (MFI) of (a) DCF (ROS formation) or (b) ethidium ${ }^{+}$uptake (pore formation) were determined by flow cytometry and results shown as means $\pm \mathrm{SD}, n=3 ;{ }^{* * *} P<0.001$ compared to corresponding basal; ${ }^{\dagger \dagger \dagger} P<0.001$ compared to corresponding ATP in the absence of NAC. (c) DIC images of cell morphology were acquired by microscopy. Bars represent $20 \mu \mathrm{m}$. Results are representative of 2 experiments. 


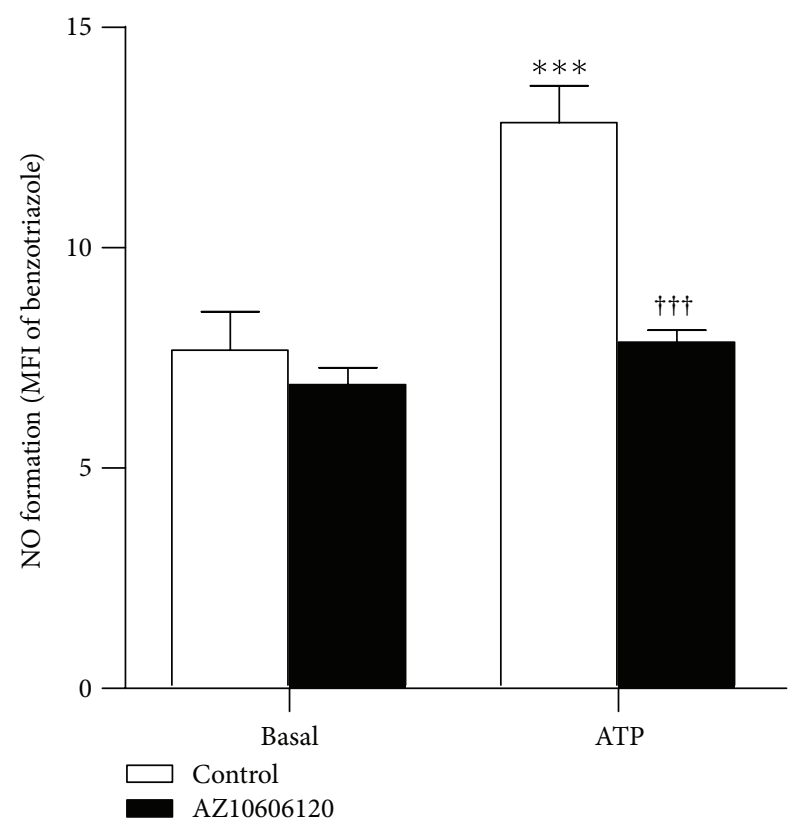

FIgURE 6: P2X7 activation induces NO formation in EOC13 microglial cells. Adherent DAF-FM DA-loaded EOC13 cells in $\mathrm{NaCl}$ medium were preincubated in the absence (control) or presence of $10 \mu \mathrm{M} \mathrm{AZ10606120} \mathrm{at} 37^{\circ} \mathrm{C}$ for $15 \mathrm{~min}$ and then in the absence (basal) or presence of $1.4 \mathrm{mM}$ ATP for $15 \mathrm{~min}$. Incubations were stopped by the addition of $\mathrm{MgCl}_{2}$ medium and centrifugation. Mean fluorescence intensities (MFI) of benzotriazole (NO formation) were determined by flow cytometry and results shown as means $\pm \mathrm{SD}, n=3 ;{ }^{* * *} P<0.001$ compared to corresponding basal; ${ }^{\dagger \dagger \dagger} P<0.001$ compared to corresponding ATP.

the ROS assay, DIC images of adherent cells were acquired following incubation in the absence or presence of ATP. Cells incubated in the absence or presence of NAC (without ATP) displayed discrete cell bodies with long, spindled shaped processes (Figure 5(c)), as previously observed [13]. Cells incubated in the absence or presence of NAC (with ATP) also displayed discrete cell bodies, but with retracted and branched processes (Figure 5(c)), typical of ATP causing membrane changes [29]. Therefore, in the ROS assay, EOC13 cell morphology was not altered by NAC when compared to the corresponding treatment.

DCF-loaded cells were also preincubated in the absence or presence of the broad-spectrum ROS inhibitor DPI and the ATP-induced ROS formation investigated. However, a $30 \mathrm{~min}$ preincubation with DPI at various concentrations (5-40 $\mu \mathrm{M})$ led to high amounts of cell death (data not shown), and thus this compound was not examined further.

To further verify that P2X7 activation induces the formation of reactive species in EOC13 cells, ATP-induced NO formation was investigated using the NO sensitive probe DAF-FM DA. Cells loaded with DAF-FM DA (which reacts with NO to form a fluorescent benzotriazole) were preincubated in the absence or presence of AZ10606120, followed by incubation in the absence or presence of ATP, and the subsequent NO formation analysed by flow cytometry. Incubation with $1.4 \mathrm{mM}$ ATP induced significant NO formation in EOC13 cells compared to cells incubated in the absence of ATP (Figure 6). Furthermore, preincubation of cells with $10 \mu \mathrm{M}$ AZ10606120 inhibited ATP-induced NO formation by $82 \pm 11 \%$ (Figure 6), indicating that this process is mediated by P2X7 activation. Again, AZ10606120 did not significantly alter the basal NO formation (Figure 6) or cell viability (as assessed by forward and side scatter) (data not shown).

3.5. P2X7 Activation Induces Cell Death in EOC13 Microglial Cells. P2X7 activation results in the death of various cell types $[11,12]$. To determine whether ATP induces the death of EOC13 microglia, cells in complete DMEM medium were incubated in the absence or presence of ATP for $24 \mathrm{~h}$, and then the percentage of Annexin- $\mathrm{V}^{+} / 7 \mathrm{AAD}^{-}$, Annexin$\mathrm{V}^{-} / 7 \mathrm{AAD}^{+}$, and Annexin- $\mathrm{V}^{+} / 7 \mathrm{AAD}^{+}$cells examined by flow cytometry (Figure 7(a)). Cell death is expressed as the total of dying (Annexin- $\mathrm{V}^{+} / 7 \mathrm{AAD}^{-}$) and dead (Annexin$\mathrm{V}^{-} / 7 \mathrm{AAD}^{+}$and Annexin- $\mathrm{V}^{+} / 7 \mathrm{AAD}^{+}$) cells. Incubation with either 2 or $3 \mathrm{mM}$ ATP but not $1 \mathrm{mM}$ ATP resulted in significantly higher percentages of total cell death compared to cells incubated in the absence of ATP (Figure 7(a)). Next, to determine if the ATP-induced EOC13 death was mediated by $\mathrm{P} 2 \mathrm{X} 7$ activation, cells were preincubated in the absence or presence of AZ10606120 and then incubated in the absence or presence of ATP for $24 \mathrm{~h}$. As above (Figure 7(a)), $2 \mathrm{mM}$ ATP induced significant cell death, with higher percentages of total cell death compared to cells incubated in the absence of ATP (Figure 7(b)). Preincubation with $10 \mu \mathrm{M}$ AZ10606120 completely inhibited ATP-induced cell death (Figure 7(b)), indicating that this process is mediated by $\mathrm{P} 2 \mathrm{X} 7$ activation.

P2X7-induced death of murine RAW264.7 macrophages is mediated by ROS formation [30]. Therefore, a role for ROS in P2X7-induced death of EOC13 microglia was investigated. To confirm that P2X7 induced ROS formation under conditions used to induce cell death, DCF-loaded EOC13 cells in complete DMEM medium were incubated in the absence or presence of ATP, and then subsequent ROS formation determined by flow cytometry. Similar to ATP-induced cell death (Figure 7(a)), incubation with 2 or 3 but not $1 \mathrm{mM}$ ATP induced significant ROS formation in EOC13 cells compared to cells incubated in the absence of ATP (Figure $7(\mathrm{c})$ ). The requirement for higher ATP concentrations to induce cell death (Figure 7(a)) or ROS formation (Figure $7(\mathrm{c})$ ) compared to pore formation (Figure 3(b)) is in line with the inhibitory action of divalent cations [15], which are present in the culture medium but not in the $\mathrm{NaCl}$ medium used. To confirm that this ROS formation was mediated by P2X7, cells were preincubated with AZ10606120 and the amounts of ATP-induced ROS formation determined. To parallel the cell death experiments, $2 \mathrm{mM}$ ATP was utilised. Again, ATP induced significant ROS formation compared to cells incubated in the absence of ATP (Figure 7(d)). Preincubation with $10 \mu \mathrm{M}$ AZ10606120 completely inhibited this ATP-induced ROS formation (Figure 7(d)).

Finally, the effect of NAC on P2X7-induced cell death was investigated. EOC13 cells were preincubated in the absence or presence of NAC followed by ATP for $24 \mathrm{~h}$. However, $24 \mathrm{~h}$ incubation with $40 \mathrm{mM}$ NAC in the absence of ATP led to 


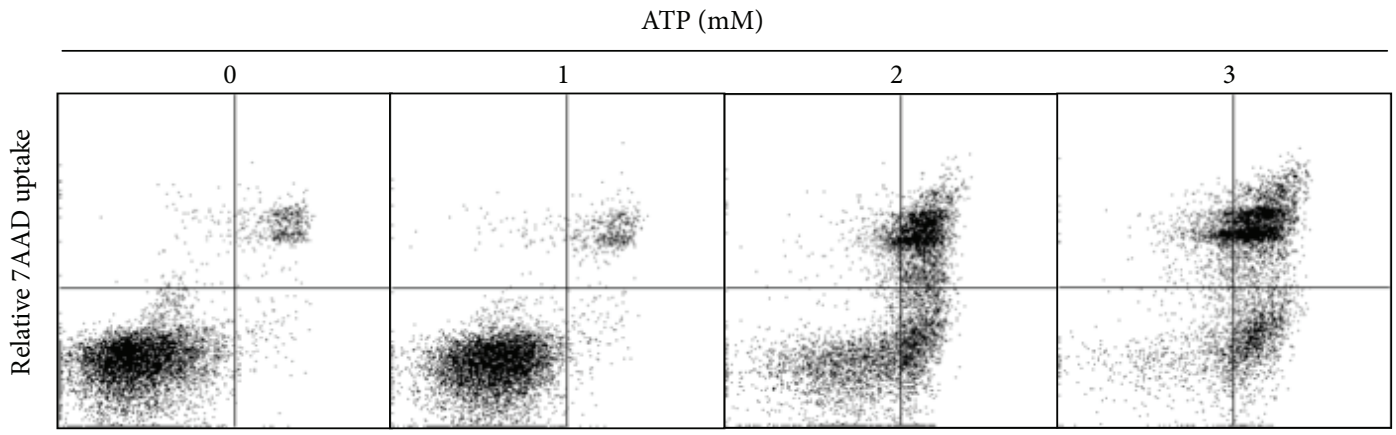

Relative Annexin-V binding

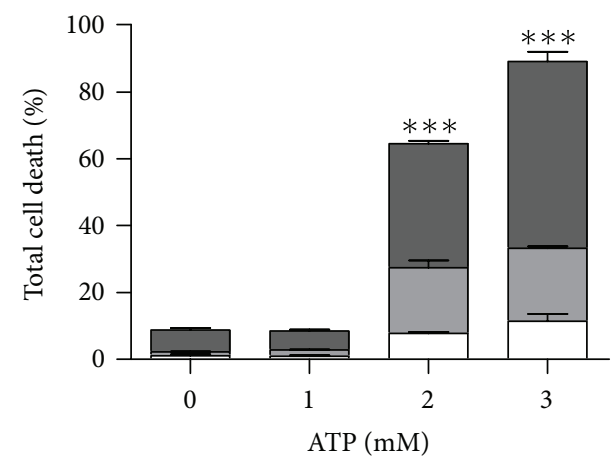

$\square$ Annexin- $\mathrm{V}^{+} / 7 \mathrm{AAD}^{+}$
$\square$ Annexin- $\mathrm{V}^{+} / 7 \mathrm{AAD}^{-}$
$\square$ Annexin- $\mathrm{V}^{-} / 7 \mathrm{AAD}^{+}$

(a)

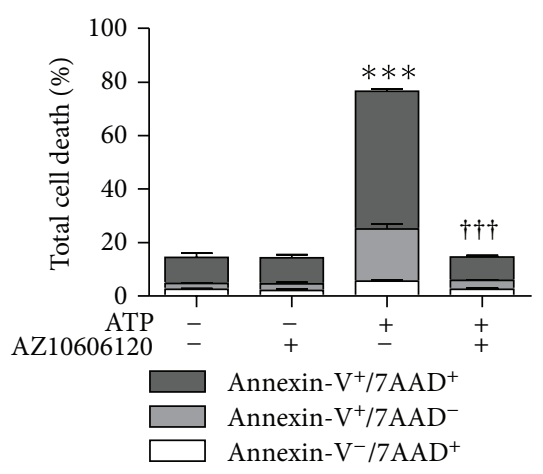

(b)

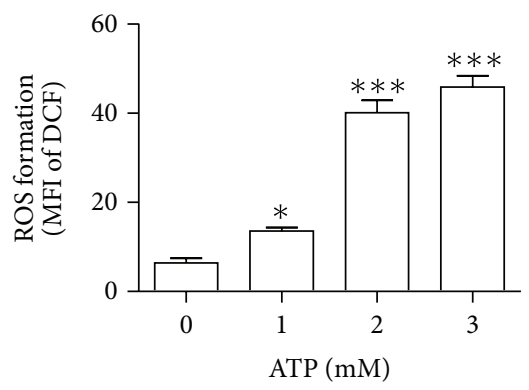

(c)

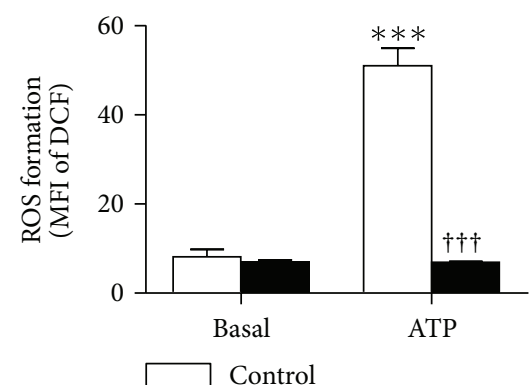

AZ10606120

NAC ATP

(90 min) (min)

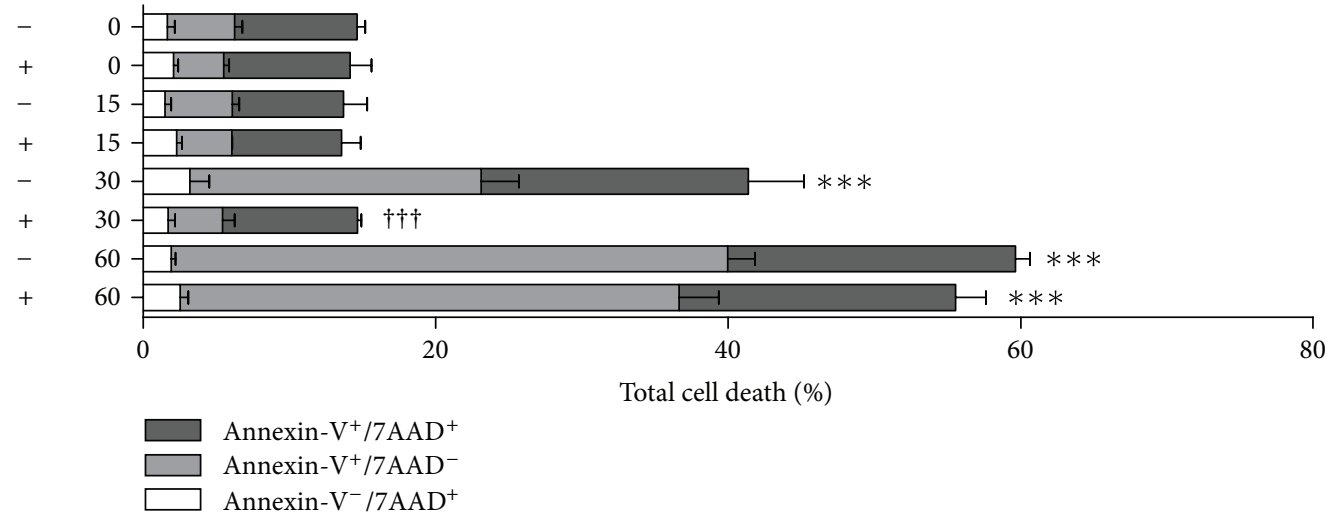

(e)

FIGURE 7: Continued. 


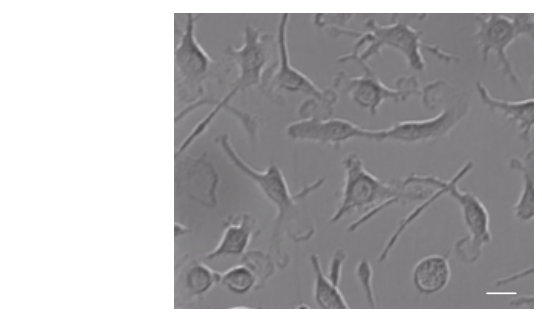

NAC $(90 \mathrm{~min})$

$\operatorname{ATP}(45 \mathrm{~min})$

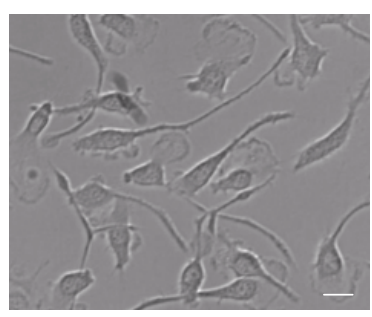

$+$

$-$

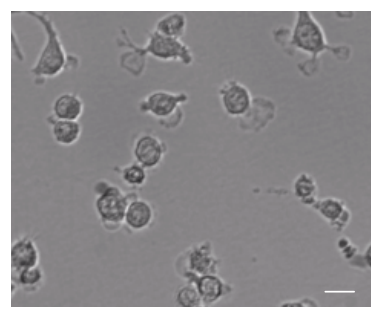

$-$

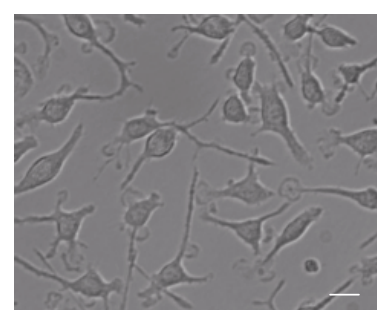

$+$

$+$

(f)

FIGURE 7: P2X7 activation induces cell death in EOC13 microglial cells. (a) Adherent EOC13 cells in complete DMEM medium were incubated in the absence or presence of varying concentrations of ATP (as indicated) at $37^{\circ} \mathrm{C}$ for $24 \mathrm{~h}$. (b) Adherent cells in complete DMEM medium were preincubated in the absence or presence of $10 \mu \mathrm{M} \mathrm{AZ10606120}$ at $37^{\circ} \mathrm{C}$ for $15 \mathrm{~min}$ and then in the absence or presence of $2 \mathrm{mM}$ ATP for $24 \mathrm{~h}$. (e and f) Adherent cells in complete DMEM medium were incubated in the absence or presence of $40 \mathrm{mM} \mathrm{NAC}$ at $37^{\circ} \mathrm{C}$ for $90 \mathrm{~min}$ and incubated in the absence or presence of $2 \mathrm{mM} \mathrm{ATP}$ for the final (e) 15-60 min or (f) $45 \mathrm{~min}$ (of the 90 min incubation), and then the medium replaced with fresh complete DMEM medium for $24 \mathrm{~h}$. (a, b, and e) Cells were harvested, labelled with Annexin-V-Fluorescein and 7AAD, and the percentage of Annexin- $\mathrm{V}^{-} / 7 \mathrm{AAD}^{+}$, Annexin- $\mathrm{V}^{+} / 7 \mathrm{AAD}^{-}$, and Annexin- $\mathrm{V}^{+} / 7 \mathrm{AAD}^{+}$cells (together representing total cell death) determined by flow cytometry. (f) DIC images of cell morphology were acquired by microscopy. Bars represent $20 \mu \mathrm{m}$. (c) Adherent DCF-loaded cells in complete DMEM medium were incubated in the absence (basal) or presence of varying concentrations of ATP (as indicated) at $37^{\circ} \mathrm{C}$ for $15 \mathrm{~min}$. (d) Adherent DCF-loaded cells in complete DMEM medium were preincubated in the absence (control) or presence of $10 \mu \mathrm{M} \mathrm{AZ10606120}$ at $37^{\circ} \mathrm{C}$ for $15 \mathrm{~min}$ and then in the absence (basal) or presence of $2 \mathrm{mM} \mathrm{ATP}$ for $15 \mathrm{~min}$. (c and d) Incubations were stopped by the addition of $\mathrm{MgCl}_{2}$ medium and centrifugation. Mean fluorescence intensity (MFI) of DCF (ROS formation) was determined by flow cytometry. Results shown as (a) dot plots of one representative set of data demonstrating the quadrant markers and (a-e) means $\pm \mathrm{SD}, n=3 ;{ }^{* * *} P<0.001$ or ${ }^{*} P<0.05$ compared to (a and c) $0 \mathrm{mM} \mathrm{ATP}$, (b and d) corresponding basal, or (e) corresponding 0 min ATP; ${ }^{\dagger \dagger} P<0.001$ compared to corresponding ATP in the absence of (b and d) AZ10606120 or (e) NAC.

significant amounts of EOC13 cell death (data not shown). Therefore, to reduce the total exposure to $40 \mathrm{mM}$ NAC, cells were incubated in the absence or presence of NAC for $90 \mathrm{~min}$, with ATP added in the final 15-60 min. The medium was then replaced with fresh complete DMEM medium and the cells incubated for $24 \mathrm{~h}$. Incubation with $2 \mathrm{mM}$ ATP for 30 or $60 \mathrm{~min}$ but not $15 \mathrm{~min}$ resulted in significant cell death compared to cells incubated in the absence of ATP (Figure $7(\mathrm{e}))$. In contrast to the $24 \mathrm{~h}$ incubation with NAC, $90 \mathrm{~min}$ incubation with $40 \mathrm{mM}$ NAC (without ATP) did not induce significant cell death compared to cells incubated for the same length of time in the absence of both NAC and ATP (Figure $7(\mathrm{e}))$. A 60 min preincubation with NAC inhibited cell death induced by 30 min incubation with ATP by $99 \pm 6 \%$ (Figure $7(\mathrm{e}))$. In contrast, a 75 and 30 min preincubation with NAC, followed by 15 and 60 min ATP treatment, respectively, had no effect on the percentage of cell death compared to cells incubated for the same time length with ATP in the absence of NAC (Figure 7(e)).

To further confirm that NAC did not induce morphological changes or cause cytotoxicity under the conditions used for the cell death assay, DIC images of adherent cells were acquired following the $24 \mathrm{~h}$ incubation. As above (Figure $5(c))$, cells incubated in the absence or presence of NAC (without ATP) displayed discrete cell bodies with long, spindled shaped processes (Figure $7(\mathrm{f})$ ). In addition, cells incubated in the presence of NAC and ATP displayed a similar morphology to that of cells incubated in the absence of ATP (Figure 7(f)). In contrast, cells preincubated with ATP alone displayed rounded and granular cell bodies with no or few processes (Figure 7(f)), characteristic of cell death.
Furthermore, wells preincubated with ATP alone had a high amount of nonadherent cells compared to the other treatments (data not shown). Thus, preincubation with NAC prevented the morphological changes associated with ATP incubation, but NAC alone had no effect on cell morphology.

\section{Discussion}

The current study demonstrates for the first time that the murine microglial EOC13 cell line expresses functional $\mathrm{P} 2 \mathrm{X} 7$. Firstly, the presence of $\mathrm{P} 2 \mathrm{X} 7 \mathrm{mRNA}$ and protein was established using RT-PCR and immunoblotting techniques. In addition, the presence of cell-surface P2X7 was demonstrated using immunofluorescence staining. Moreover, P2X7 on EOC13 microglia was functional, as the P2X7 agonists ATP and BzATP induced significant ethidium ${ }^{+}$or YO-PRO- ${ }^{2+}$ uptake into these cells. In these experiments, ATP induced ethidium ${ }^{+}$uptake with an $\mathrm{EC}_{50}$ value which falls within the typical range for ATP-induced cation fluxes mediated by recombinant murine P2X7 [31]. Furthermore, pretreatment of cells with P2X7 antagonists inhibited ATPinduced organic cation uptake. Lastly, ATP could induce ROS formation in and the death of EOC13 cells, and both of these events, which are often associated with P2X7 activation [1012], could be inhibited by the P2X7 antagonist AZ10606120. The presence of functional P2X7 on EOC13 microglia is consistent with the presence of this receptor on primary microglia and microglial cell lines (including N9, N13, BV2, and NTW8 cells) [32-35]. 
P2X7 activation induced ROS formation in EOC13 microglia. P2X7-induced ROS formation has been reported in primary microglia [24, 25], and a role for this process in microglia has been highlighted by several studies. P2X7 activation induces the production of the ROS, superoxide, in primary rat microglia, while this receptor is upregulated in a transgenic mouse model of Alzheimer's disease [25]. Although a direct link between P2X7, superoxide, and Alzheimer's disease was not established, the authors proposed a link between these molecules and this disease. This link is supported by subsequent observations by others, where fibrillar $\beta$-amyloid peptide, which is associated with Alzheimer's disease, caused ATP release and autocrine activation of P2X7 leading to ROS formation in primary rat microglia [24]. In addition, another group demonstrated that P2X7-induced superoxide release from primary rat microglia induced injury of rat cortical neurons [36]. Collectively, this data indicates that P2X7-induced ROS formation from microglia may be involved in various neuroinflammatory and neurodegenerative disorders. This may be of particular importance in diseases where microglial P2X7 is reported to be upregulated such as in Alzheimer's disease, multiple sclerosis, and amyotrophic lateral sclerosis [25, 37]. It should be noted, however, that DCF, as employed in the current study and as widely used by others to detect ROS, can also propagate ROS formation [38]. Nevertheless, our observation that P2X7 activation also induces the formation of $\mathrm{NO}$ in EOC13 cells supports a role for this receptor in the formation of reactive species.

The current study excluded an essential role for $\mathrm{Ca}^{2+}$ influx in P2X7-induced ROS formation in EOC13 microglia. This finding is similar to other observations with other murine cell types, including submandibular glands [39] and erythroid cells [40]. In contrast, P2X7-induced ROS formation in primary rat microglia [24] and rat submandibular glands [27] is dependent on an influx of $\mathrm{Ca}^{2+}$. The reason for this difference between these two species remains unknown but may reflect differences in experimental protocols or differences in signalling molecules between mice and rats. The current study also excluded an essential role for $\mathrm{K}^{+}$ efflux in P2X7-induced ROS formation in EOC13 microglia. Both ROS formation and $\mathrm{K}^{+}$efflux are involved in IL- $1 \beta$ release from monocytes, although whether these downstream processes are linked has not been established [28]. Thus, our results indicate that $\mathrm{P} 2 \mathrm{X} 7$-induced ROS formation does not require $\mathrm{K}^{+}$efflux and that ROS formation and $\mathrm{K}^{+}$efflux may be independent events in IL- $1 \beta$ release from myeloid cells.

P2X7 activation also induced cell death in EOC13 microglia. Use of an Annexin-V/7AAD assay suggested that this process was mediated by apoptosis. However, in the absence of other markers of apoptosis and necrosis, this remains to be established, especially since $\mathrm{P} 2 \mathrm{X} 7$ activation induces both apoptosis and necrosis in the microglial N13 cell line [41]. Nevertheless, our observations support previous studies in which P2X7 activation induced death in primary microglia and other microglial cell lines [41, 42]. The physiological role of $\mathrm{P} 2 \mathrm{X} 7$-induced microglia death is unclear. Further obscuring this is the known role of P2X7 activation in inducing the proliferation of microglia [43]. This paradoxical role of $\mathrm{P} 2 \mathrm{X} 7$ is thought to be related to the relative ATP concentration, with high concentrations promoting cell death and low concentrations promoting cell proliferation [44]. In support of this, our study observed that ATP only induced EOC13 cell death at 2 or 3 but not $1 \mathrm{mM}$ ATP. Moreover, our data also showed that a transient incubation with ATP of 30-60 but not 15 min induced cell death in EOC13 microglia. This suggests that transient ATP release and subsequent P2X7 activation may be sufficient to kill microglia in vivo.

The current study examined a potential link between P2X7-induced ROS formation and death in EOC13 microglia. A previous study demonstrated that the ATPinduced death of murine RAW264.7 macrophages was mediated by ROS derived from NADPH oxidase downstream of P2X7 activation [30]. This contrasts with another study, which found that P2X7-induced ROS formation, but not death, was attenuated in primary macrophages from NADPH oxidase deficient mice [45]. Our data using the ROS scavenger NAC supports a role for ROS formation in the P2X7-induced death of EOC13 microglia. The capacity of NAC to prevent P2X7-induced EOC13 microglia death was dependent on the preincubation time with NAC, as well as the total incubation time with ATP, with only 45-60 min preincubations with NAC preventing cell death induced by transient $30-45 \mathrm{~min}$ exposures to ATP. In contrast, $24 \mathrm{~h}$ incubation with NAC induced significant amounts of EOC13 microglia death, equivalent to that induced by ATP alone. This cytotoxicity of NAC may have occurred due to increased toxic metabolic byproducts such as reduced glutathione [46]. Alternatively, scavenging of ROS by NAC may indicate that low amounts of ROS are important for EOC13 cell homeostasis. Of note, the ROS inhibitor DPI also induced the death of EOC13 microglia, albeit over a much faster time course. Finally, it should be noted that NAC inhibition of P2X7-induced death and ROS formation in EOC13 microglia may have been partly due to direct inhibition of P2X7. NAC inhibited ATP-induced pore formation by $30 \%$ compared to a 74 and $99 \%$ inhibition of ATP-induced ROS formation and cell death, respectively. This direct inhibition of P2X7 by NAC was not due to an acidic $\mathrm{pH}$, which is known to impair P2X7 function [47], as the NAC-containing solutions were adjusted to $\mathrm{pH} 7.4$ before each assay. Thus, our results indicate that either cellular signalling involving ROS may modulate P2X7 activation in EOC13 microglia or that NAC may directly impair P2X7 at $40 \mathrm{mM}$. The concentration of NAC used in these experiments $(40 \mathrm{mM})$ is 4-8-fold higher than that used in a number of similar studies (e.g., [48]). The requirement for this high concentration of NAC remains unknown but may reflect a reduced ability of NAC to cross the plasma membrane or to be converted to glutathione in EOC13 cells.

The presence of functional P2X7 on J774 macrophage cells was confirmed in the current study. P2X7 is present in this cell line [17], and activation of P2X7 leads to the release of mature IL- $1 \beta$ [49], the formation of macrophage-derived multinucleated giant cells [50-52], and cell death [53]. In this 
study, the potency of four P2X7 antagonists against $1 \mathrm{mM}$ ATP, the ATP concentration most commonly used to study $\mathrm{P} 2 \mathrm{X} 7$, was determined. The $\mathrm{IC}_{50}$ values for BBG, A438079, and $\operatorname{AZ11645373}(1.8,7.9$, and $1.5 \mu \mathrm{M}$, resp.) were within one log range of those published for recombinant murine P2X7 $[54,55]$. In contrast, the $\mathrm{IC}_{50}$ value for $\mathrm{AZ} 10606120$ has not been reported for murine P2X7, although this compound has been shown to specifically bind to and inhibit rat and human P2X7 [20]. In the current study, this highly specific P2X7 antagonist also completely impaired ATP-induced ethidium ${ }^{+}$ uptake, ROS formation, and death of murine EOC13 cells. Thus, AZ10606120 will be useful for future studies of murine P2X7.

In the CNS, extracellular ATP acting through P2X7 on microglia is an important mediator of neuroinflammation [9]. ATP acts as a neurotransmitter and is released from neurons during synaptic transmission and from dying cells [56]. Under normal physiological conditions, extracellular ATP concentrations in the CNS are estimated to be in the nanomolar to micromolar range, depending on the balance between ATP release and degradation, while intracellular microglial ATP concentrations are in the millimolar range [57]. After CNS injury, however, extracellular ATP concentrations increase and can reach as high as the millimolar range [57]. Furthermore, it is hypothesised that ATP may act on microglial P2X7 at very close range where the concentration of ATP may be quite high. Activation of P2X7 on primary microglia and microglial cell lines leads to the release of proinflammatory IL- $1 \beta$ and tumour necrosis factor- $\alpha$ $[33,58]$ and ROS formation [24]. Although proinflammatory factors are important for immunity [1], prolonged or inappropriate release of such factors from chronically activated microglial can be highly toxic to neurons and can promote neuroinflammation and neurodegeneration [5]. There are a number of diseases in the CNS characterised by the presence of activated microglia, including Alzheimer's disease, prion infection, cerebral ischemia, multiple sclerosis, and amyotrophic lateral sclerosis. In such diseases, P2X7 has also been reported to be upregulated $[25,37,59,60]$. This raises questions of possible roles for P2X7 in mediating inappropriate microglial responses in CNS disorders.

\section{Conclusions}

This study demonstrates that EOC13 microglial cells express functional P2X7. Activation of this receptor by ATP resulted in organic cation uptake, ROS formation, and death in these cells. Moreover, the EOC13 cell line may be useful for investigating P2X7-mediated events in microglia and the role of this receptor in microglia-mediated inflammatory disorders.

\section{Abbreviations}

7AAD: 7-Aminoactinomycin D

Ab: Polyclonal antibody

APC: Allophycocyanin

\begin{tabular}{|c|c|}
\hline ATP: & Adenosine $-5^{\prime}$-triphosphate \\
\hline BBG: & Brilliant Blue G \\
\hline BzATP: & $2^{\prime}\left(3^{\prime}\right)$-O-(4-Benzoylbenzoyl) ATP \\
\hline CNS: & Central nervous system \\
\hline DAF-FM DA: & $2^{\prime}, 7^{\prime}$-Difluorofluorescein diacetate \\
\hline DCF: & Dichlorofluorescein \\
\hline DIC: & Differential interference contrast \\
\hline DMSO: & Dimethyl sulfoxide \\
\hline DPI: & Diphenyleneiodonium \\
\hline $\mathrm{EC}_{50}:$ & Half maximal effective concentration \\
\hline EGTA: & Ethylene glycol tetraacetic acid \\
\hline FBS: & Fetal bovine serum \\
\hline $\mathrm{H}_{2}$ DCFDA: & $\begin{array}{l}2^{\prime}, 7^{\prime} \text {-Dichlorodihydrofluorescein } \\
\text { diacetate }\end{array}$ \\
\hline $\mathrm{IC}_{50}:$ & $\begin{array}{l}\text { Half maximal inhibitory } \\
\text { concentration }\end{array}$ \\
\hline IL-1 $\beta$ : & Interleukin- $1 \beta$ \\
\hline mAb: & Monoclonal antibody \\
\hline MFI: & Mean fluorescence intensity \\
\hline NAC: & N-Acetyl-L-cysteine \\
\hline NHS: & Normal horse serum \\
\hline NO: & Nitric oxide \\
\hline PBS: & Phosphate-buffered saline \\
\hline PMSF: & Phenyl-methyl-sulfonyl-fluoride \\
\hline ROS: & Reactive oxygen species. \\
\hline
\end{tabular}

\section{Acknowledgments}

This work was supported by the University of Wollongong, the Motor Neurone Disease Research Institute, the National Health and Research Council of Australia, and the Australian Research Council. R. Bartlett is the recipient of an Australian Postgraduate Award. J. J. Yerbury is the recipient of a Bill Gole Postdoctoral Fellowship. Technical assistance by the staff of the Illawarra Health and Medical Research Institute is also gratefully acknowledged. The authors declare no conflict of interests and no financial relation with any company.

\section{References}

[1] A. Nimmerjahn, F. Kirchhoff, and F. Helmchen, "Neuroscience: resting microglial cells are highly dynamic surveillants of brain parenchyma in vivo," Science, vol. 308, no. 5726, pp. 1314-1318, 2005.

[2] K. Helmut, U. K. Hanisch, M. Noda, and A. Verkhratsky, "Physiology of microglia," Physiological Reviews, vol. 91, no. 2, pp. 461-553, 2011.

[3] U. K. Hanisch and H. Kettenmann, "Microglia: active sensor and versatile effector cells in the normal and pathologic brain," Nature Neuroscience, vol. 10, no. 11, pp. 1387-1394, 2007.

[4] R. M. Ransohoff and V. H. Perry, "Microglial physiology: unique stimuli, specialized responses," Annual Review of Immunology, vol. 27, pp. 119-145, 2009.

[5] M. L. Block and J. S. Hong, "Microglia and inflammationmediated neurodegeneration: multiple triggers with a common mechanism," Progress in Neurobiology, vol. 76, no. 2, pp. 77-98, 2005.

[6] M. Monif, G. Burnstock, and D. A. Williams, "Microglia: proliferation and activation driven by the P2X7 receptor," 
International Journal of Biochemistry and Cell Biology, vol. 42, no. 11, pp. 1753-1756, 2010.

[7] M. F. Jarvis and B. S. Khakh, "ATP-gated P2X cation-channels," Neuropharmacology, vol. 56, no. 1, pp. 208-215, 2009.

[8] J. S. Wiley, R. Sluyter, B. J. Gu, L. Stokes, and S. J. Fuller, "The human P2X7 receptor and its role in innate immunity," Tissue Antigens, vol. 78, no. 5, pp. 321-332, 2011.

[9] S. Duan and J. T. Neary, "P2X7 receptors: properties and relevance to CNS function," GLIA, vol. 54, no. 7, pp. 738-746, 2006.

[10] J. Hewinson and A. B. MacKenzie, "P2X7 receptor-mediated reactive oxygen and nitrogen species formation: from receptor to generators," Biochemical Society Transactions, vol. 35, no. 5, pp. 1168-1170, 2007.

[11] E. Adinolfi, C. Pizzirani, M. Idzko et al., "P2X7 receptor: death or life?” Purinergic Signalling, vol. 1, no. 3, pp. 219-227, 2005.

[12] F. di Virgilio, D. Ferrari, and E. Adinolfi, "P2X7: a growthpromoting receptor-implications for cancer," Purinergic Signalling, vol. 5, no. 2, pp. 251-256, 2009.

[13] W. S. Walker, J. Gatewood, E. Olivas, D. Askew, and C. E. G. Havenith, "Mouse microglial cell lines differing in constitutive and interferon- $\gamma$-inducible antigen-presenting activities for naive and memory CD4+ and CD8+ T cells," Journal of Neuroimmunology, vol. 63, no. 2, pp. 163-174, 1995.

[14] P. Constantinescu, B. Wang, K. Kovacevic et al., "P2X7 receptor activation induces cell death and microparticle release in murine erythroleukemia cells," Biochimica et Biophysica Acta, vol. 1798, no. 9, pp. 1797-1804, 2010.

[15] R. A. North, "Molecular physiology of P2X receptors," Physiological Reviews, vol. 82, no. 4, pp. 1013-1067, 2002.

[16] P. W. Marks and F. R. Maxfield, "Preparation of solutions with free calcium concentration in the nanomolar range using 1,2bis(o-aminophenoxy)ethane-N,N,N'N'-tetraacetic acid," Analytical Biochemistry, vol. 193, no. 1, pp. 61-71, 1991.

[17] R. Coutinho-Silva, D. M. Ojcius, D. C. Górecki et al., "Multiple $\mathrm{P} 2 \mathrm{X}$ and P2Y receptor subtypes in mouse J774, spleen and peritoneal macrophages," Biochemical Pharmacology, vol. 69, no. 4, pp. 641-655, 2005.

[18] A. W. Farrell, S. Gadeock, A. Pupovac et al., "P2X7 receptor activation induces cell death and CD23 shedding in human RPMI 8226 multiple myeloma cells," Biochimica et Biophysica Acta, vol. 1800, no. 11, pp. 1173-1182, 2010.

[19] D. W. Nelson, R. J. Gregg, M. E. Kort et al., "Structure-activity relationship studies on a series of novel, substituted 1-benzyl-5phenyltetrazole P2X7 antagonists," Journal of Medicinal Chemistry, vol. 49, no. 12, pp. 3659-3666, 2006.

[20] A. D. Michel, L. J. Chambers, W. C. Clay, J. P. Condreay, D. S. Walter, and I. P. Chessell, "Direct labelling of the human P2X7 receptor and identification of positive and negative cooperativity of binding," British Journal of Pharmacology, vol. 151, no. 1, pp. 84-95, 2007.

[21] L. Stokes, L. H. Jiang, L. Alcaraz et al., "Characterization of a selective and potent antagonist of human P2X7 receptors, AZ11645373," British Journal of Pharmacology, vol. 149, no. 7, pp. 880-887, 2006.

[22] N. D’Ambrosi, P. Finocchi, S. Apolloni et al., "The proinflammatory action of microglial P2 receptors is enhanced in SOD1 models for amyotrophic lateral sclerosis," Journal of Immunology, vol. 183, no. 7, pp. 4648-4656, 2009.

[23] M. Díaz-Hernández, M. Díez-Zaera, J. Sánchez-Nogueiro et al., "Altered P2X7-receptor level and function in mouse models of Huntington's disease and therapeutic efficacy of antagonist administration," FASEB Journal, vol. 23, no. 6, pp. 1893-1906, 2009.

[24] Y. K. Soo, H. M. Ju, G. L. Hwan, U. K. Seung, and B. L. Yong, "ATP released from $\beta$-amyloid-stimulated microglia induces reactive oxygen species production in an autocrine fashion," Experimental and Molecular Medicine, vol. 39, no. 6, pp. 820-827, 2007.

[25] L. K. Parvathenani, S. Tertyshnikova, C. R. Greco, S. B. Roberts, B. Robertson, and R. Posmantur, "P2X7 mediates superoxide production in primary microglia and is up-regulated in a transgenic mouse model of Alzheimer's disease," Journal of Biological Chemistry, vol. 278, no. 15, pp. 13309-13317, 2003.

[26] B. C. Suh, J. S. Kim, U. Namgung, H. Ha, and K. T. Kim, "P2X7 nucleotide receptor mediation of membrane pore formation and superoxide generation in human promyelocytes and neutrophils," Journal of Immunology, vol. 166, no. 11, pp. 6754-6763, 2001.

[27] U. Fontanils, M. Seil, S. Pochet et al., "Stimulation by P2X7 receptors of calcium-dependent production of reactive oxygen species (ROS) in rat submandibular glands," Biochimica et Biophysica Acta, vol. 1800, no. 11, pp. 1183-1191, 2010.

[28] F. Martinon, A. Mayor, and J. Tschopp, "The inflammasomes: guardians of the body," Annual Review of Immunology, vol. 27, pp. 229-265, 2009.

[29] Y. Qu and G. R. Dubyak, "P2X7 receptors regulate multiple types of membrane trafficking responses and non-classical secretion pathways," Purinergic Signalling, vol. 5, no. 2, pp. 163-173, 2009.

[30] T. Noguchi, K. Ishii, H. Fukutomi et al., "Requirement of reactive oxygen species-dependent activation of ASK1-p38 MAPK pathway for extracellular ATP-induced apoptosis in macrophage," Journal of Biological Chemistry, vol. 283, no. 12, pp. 7657-7665, 2008.

[31] I. P. Chessell, J. Simon, A. D. Hibell, A. D. Michel, E. A. Barnard, and P. P. A. Humphrey, "Cloning and functional characterisation of the mouse P2X7 receptor," FEBS Letters, vol. 439, no. 1-2, pp. 26-30, 1998.

[32] D. Ferrari, P. Chiozzi, S. Falzoni et al., "ATP-mediated cytotoxicity in microglial cells," Neuropharmacology, vol. 36, no. 9, pp. 1295-1301, 1997.

[33] D. Ferrari, M. Villalba, P. Chiozzi, S. Falzoni, P. RicciardiCastagnoli, and F. di Virgilio, "Mouse microglial cells express a plasma membrane pore gated by extracellular ATP," Journal of Immunology, vol. 156, no. 4, pp. 1531-1539, 1996.

[34] I. P. Chessell, A. D. Michel, and P. P. A. Humphrey, "Properties of the pore-forming P2X7 purinoceptor in mouse NTW8 microglial cells," British Journal of Pharmacology, vol. 121, no. 7, pp. 1429-1437, 1997.

[35] F. P. Gendron, M. Chalimoniuk, J. Strosznajder et al., "P2X7 nucleotide receptor activation enhances IFN $\gamma$-induced type II nitric oxide synthase activity in BV-2 microglial cells," Journal of Neurochemistry, vol. 87, no. 2, pp. 344-352, 2003.

[36] S. D. Skaper, L. Facci, A. A. Culbert et al., "P2X7 receptors on microglial cells mediate injury to cortical neurons in vitro," GLIA, vol. 54, no. 3, pp. 234-242, 2006.

[37] Y. Yiangou, P. Facer, P. Durrenberger et al., "COX-2, CB2 and P2X7-immunoreactivities are increased in activated microglial cells/macrophages of multiple sclerosis and amyotrophic lateral sclerosis spinal cord," BMC Neurology, vol. 6, article 12, 2006.

[38] X. Chen, Z. Zhong, Z. Xu, L. Chen, and Y. Wang, " 2 ', $7^{\prime}$ Dichlorodihydrofluorescein as a fluorescent probe for reactive 
oxygen species measurement: forty years of application and controversy," Free Radical Research, vol. 44, no. 6, pp. 587-604, 2010.

[39] M. Seil, U. Fontanils, I. G. Etxebarria et al., "Pharmacological evidence for the stimulation of NADPH oxidase by P2X7 receptors in mouse submandibular glands," Purinergic Signalling, vol. 4, no. 4, pp. 347-355, 2008.

[40] B. Wang and R. Sluyter, "P2X7 receptor activation induces reactive oxygen species formation in erythroid cells," Purinergic Signalling. In press.

[41] D. Ferrari, M. Los, M. K. A. Bauer, P. Vandenabeele, S. Wesselborg, and K. Schulze-Osthoff, "P2Z purinoreceptor ligation induces activation of caspases with distinct roles in apoptotic and necrotic alterations of cell death," FEBS Letters, vol. 447, no. 1, pp. 71-75, 1999.

[42] D. Brough, R. A. Le Feuvre, Y. Iwakura, and N. J. Rothwell, "Purinergic (P2X7) receptor activation of microglia induces cell death via an interleukin-1-independent mechanism," Molecular and Cellular Neuroscience, vol. 19, no. 2, pp. 272-280, 2002.

[43] M. Monif, C. A. Reid, K. L. Powell, M. L. Smart, and D. A. Williams, "The $\mathrm{P} 2 \mathrm{X} 7$ receptor drives microglial activation and proliferation: a trophic role for P2X7R pore," Journal of Neuroscience, vol. 29, no. 12, pp. 3781-3791, 2009.

[44] F. di Virgilio, S. Ceruti, P. Bramanti, and M. P. Abbracchio, "Purinergic signalling in inflammation of the central nervous system," Trends in Neurosciences, vol. 32, no. 2, pp. 79-87, 2009.

[45] S. F. Moore and A. B. MacKenzie, "NADPH oxidase NOX2 mediates rapid cellular oxidation following ATP stimulation of endotoxin-primed macrophages," Journal of Immunology, vol. 183, no. 5, pp. 3302-3308, 2009.

[46] S. Qanungo, M. Wang, and A. L. Nieminen, "N-acetyl-Lcysteine enhances apoptosis through inhibition of nuclear factor- $\kappa \mathrm{B}$ in hypoxic murine embryonic fibroblasts," Journal of Biological Chemistry, vol. 279, no. 48, pp. 50455-50464, 2004.

[47] X. Liu, W. Ma, A. Surprenant, and L. H. Jiang, "Identification of the amino acid residues in the extracellular domain of rat P2X7 receptor involved in functional inhibition by acidic $\mathrm{pH}$," British Journal of Pharmacology, vol. 156, no. 1, pp. 135-142, 2009.

[48] Z. A. Pfeiffer, A. N. Guerra, L. M. Hill et al., "Nucleotide receptor signaling in murine macrophages is linked to reactive oxygen species generation," Free Radical Biology and Medicine, vol. 42, no. 10, pp. 1506-1516, 2007.

[49] P. Pelegrin, C. Barroso-Gutierrez, and A. Surprenant, "P2X7 receptor differentially couples to distinct release pathways for IL-1 $\beta$ in mouse macrophage," Journal of Immunology, vol. 180, no. 11, pp. 7147-7157, 2008.

[50] P. Chiozzi, J. M. Sanz, D. Ferrari et al., "Spontaneous cell fusion in macrophage cultures expressing high levels of the P2Z/P2X7 receptor," Journal of Cell Biology, vol. 138, no. 3, pp. 697-706, 1997.

[51] T. H. Steinberg, "P2-mediated responses in osteoclasts and osteoclast-like cells," Drug Development Research, vol. 53, no. 2-3, pp. 126-129, 2001.

[52] I. Lemaire, S. Falzoni, B. Zhang, P. Pellegatti, and F. di Virgilio, "The P2X7 receptor and pannexin-1 are both required for the promotion of multinucleated macrophages by the inflammatory cytokine GM-CSF," Journal of Immunology, vol. 187, no. 7, pp. 3878-3887, 2011.

[53] P. Chiozzi, M. Murgia, S. Falzoni, D. Ferrari, and F. di Virgilio, "Role of the purinergic P2Z receptor in spontaneous cell death in J774 macrophage cultures," Biochemical and Biophysical Research Communications, vol. 218, no. 1, pp. 176-181, 1996.
[54] D. L. Donnelly-Roberts, M. T. Namovic, P. Han, and M. F. Jarvis, "Mammalian P2X7 receptor pharmacology: comparison of recombinant mouse, rat and human P2X7 receptors," British Journal of Pharmacology, vol. 157, no. 7, pp. 1203-1214, 2009.

[55] A. D. Michel, S. W. Ng, S. Roman, W. C. Clay, D. K. Dean, and D. S. Walter, "Mechanism of action of species-selective P2X7 receptor antagonists," British Journal of Pharmacology, vol. 156, no. 8, pp. 1312-1325, 2009.

[56] B. S. Khakh and R. A. North, "P2X receptors as cell-surface ATP sensors in health and disease," Nature, vol. 442, no. 7102, pp. 527-532, 2006.

[57] H. Franke and P. Illes, "Involvement of P2 receptors in the growth and survival of neurons in the CNS," Pharmacology and Therapeutics, vol. 109, no. 3, pp. 297-324, 2006.

[58] I. Hide, M. Tanaka, A. Inoue et al., "Extracellular ATP triggers tumor necrosis factor- $\alpha$ release from rat microglia," Journal of Neurochemistry, vol. 75, no. 3, pp. 965-972, 2000.

[59] H. Franke, A. Günther, J. Grosche et al., "P2X7 receptor expression after ischemia in the cerebral cortex of rats," Journal of Neuropathology and Experimental Neurology, vol. 63, no. 7, pp. 686-699, 2004.

[60] T. Takenouchi, Y. Iwamaru, M. Imamura et al., "Prion infection correlates with hypersensitivity of P2X7 nucleotide receptor in a mouse microglial cell line," FEBS Letters, vol. 581, no. 16, pp. 3019-3026, 2007. 


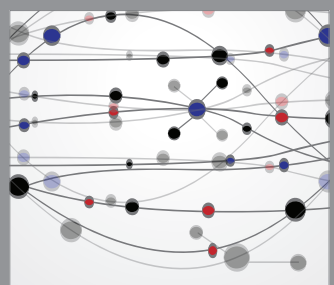

The Scientific World Journal
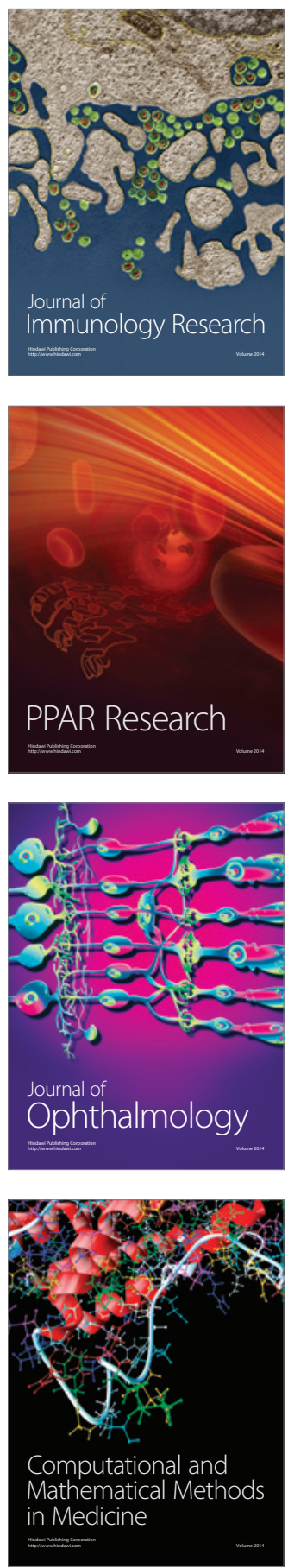

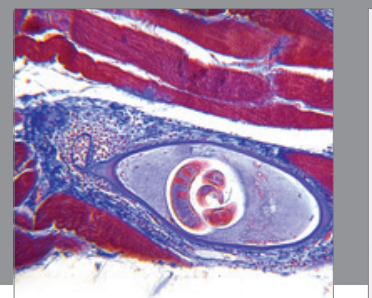

Gastroenterology

Research and Practice
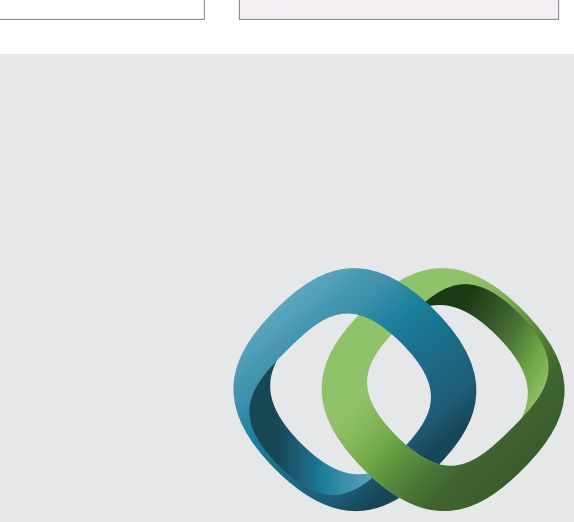

\section{Hindawi}

Submit your manuscripts at

http://www.hindawi.com
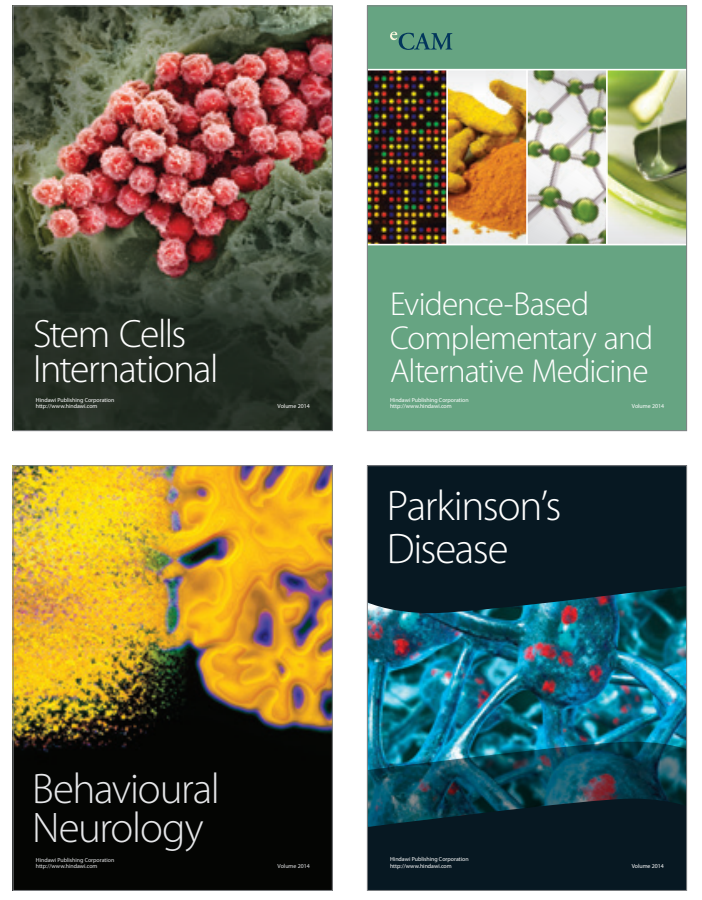
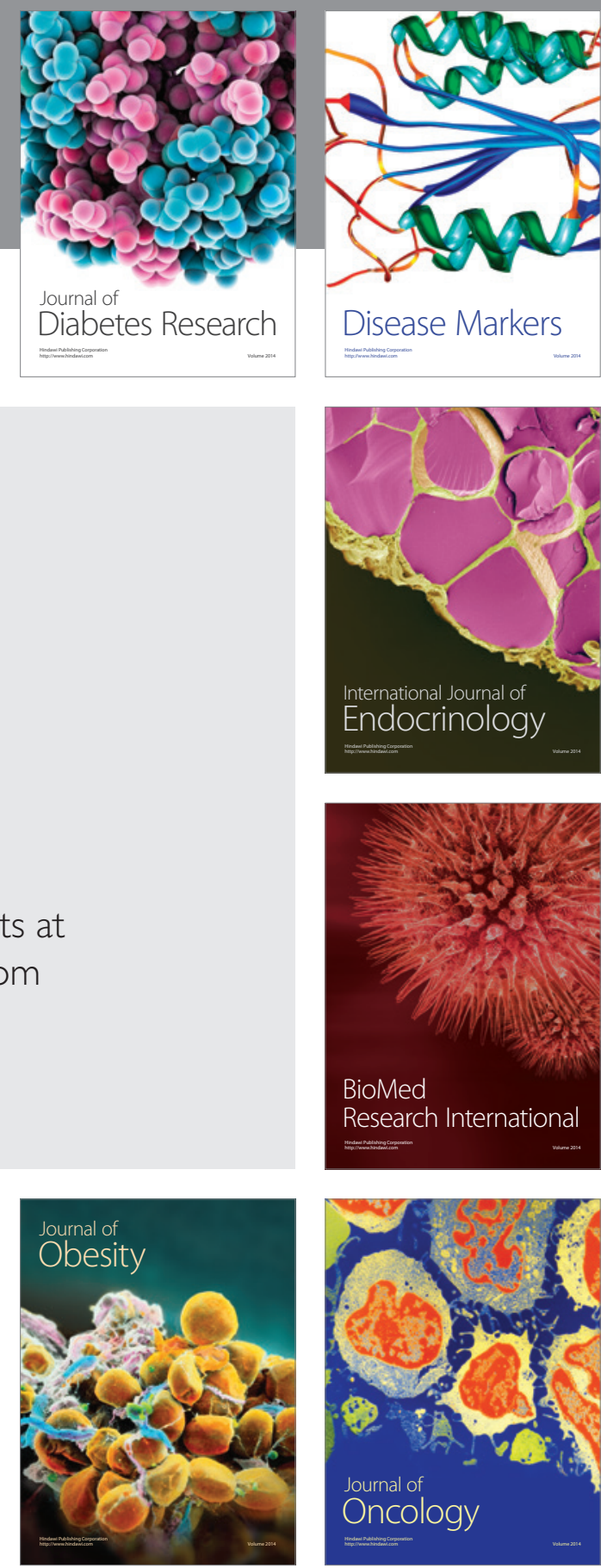

Disease Markers
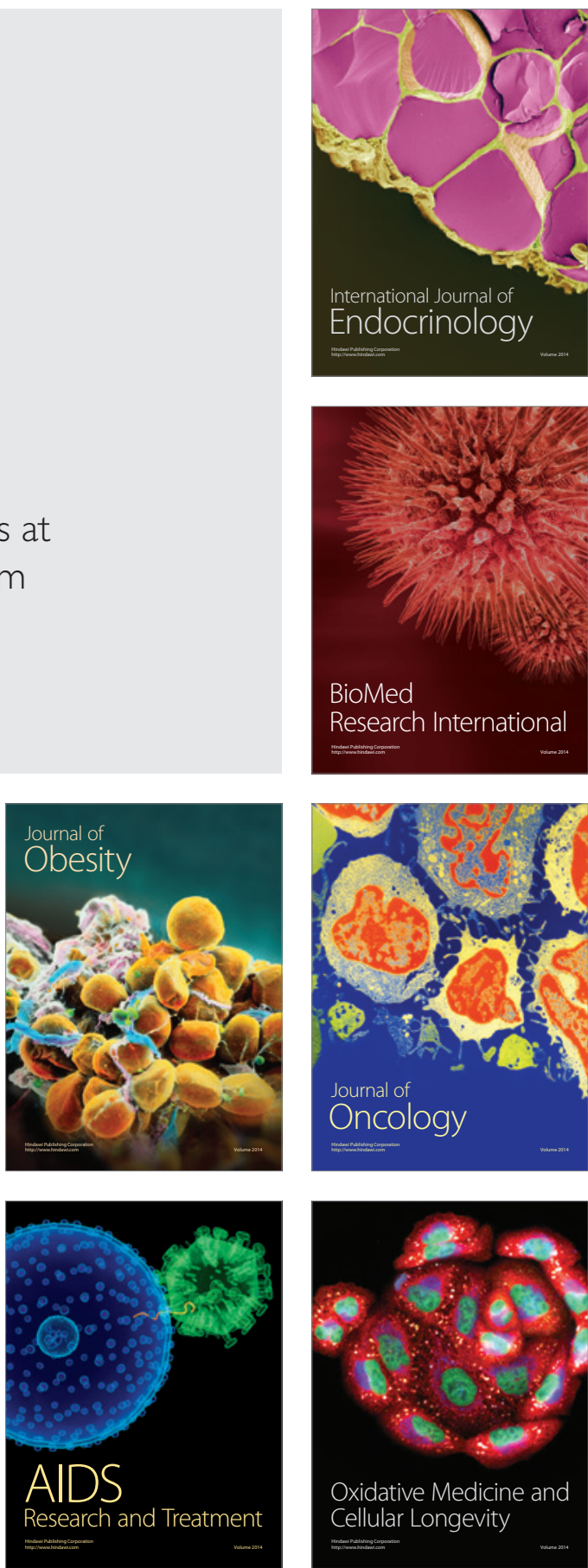